\title{
Avian thermoregulation in the heat: efficient evaporative cooling in two southern African nightjars
}

\author{
Ryan S. O’Connor ${ }^{1}$
}

Blair O. Wolf ${ }^{2}$

R. Mark Brigham ${ }^{3}$

Andrew E. McKechnie ${ }^{1, *}$

${ }^{1}$ DST-NRF Centre of Excellence at the Percy FitzPatrick Institute, Department of Zoology and Entomology, University of Pretoria, Private Bag X20, Hatfield 0028, South Africa

${ }^{2}$ UNM Biology Department, University of New Mexico, MSC03-2020, Albuquerque, NM 847131-0001, USA

${ }^{3}$ Department of Biology, University of Regina, Regina, Saskatchewan S4S 0A2, Canada

*Author for correspondence E-mail: aemckechnie@ zoology.up.ac.za; Tel.: +27 (0)12-420 6471; Fax: +27

(0)12-362 5242

\section{${ }^{1}$ Abbreviations}

\footnotetext{
${ }^{1}$ EHL evaporative heat loss; $\mathrm{M}_{\mathrm{b}}$ body mass; MHP metabolic heat production; RMR resting metabolic rate; $\mathrm{T}_{\mathrm{a}}$ air temperature; $\mathrm{T}_{\mathrm{b}}$ body temperature; $\mathrm{T}_{\mathrm{e}}$ operative temperature; TEWL total evaporative water loss; $\mathrm{T}_{\mathrm{lc}}$ lower critical limit of thermoneutrality; $\mathrm{T}_{\mathrm{uc}}$ upper critical limit of thermoneutrality
} 


\section{Abstract}

Nightjars represent a model taxon for investigating physiological limits of heat tolerance because of their habit of roosting and nesting in sunlit sites during the heat of the day. We investigated the physiological responses of Rufous-cheeked Nightjars (Caprimulgus rufigena) and Freckled Nightjars (Caprimulgus tristigma) to high air temperatures $\left(\mathrm{T}_{\mathrm{a}}\right)$ by measuring $T_{b}$, resting metabolic rate (RMR) and total evaporative water loss (TEWL) at $T_{a}$ ranging from $10-56{ }^{\circ} \mathrm{C}$. Both species became hyperthermic at $\mathrm{T}_{\mathrm{a}}>\mathrm{T}_{\mathrm{b}}$. Lower critical limits of thermoneutrality occurred at $\mathrm{T}_{\mathrm{a}}$ between 35 and $37{ }^{\circ} \mathrm{C}$, whereas we detected no clear upper critical limits of thermoneutrality. Between $\mathrm{T}_{\mathrm{a}} \approx 37.0$ and $39.9^{\circ} \mathrm{C}$, rates of TEWL increased rapidly with $\mathrm{T}_{\mathrm{a}}$. At $\mathrm{T}_{\mathrm{a}} \geq 40{ }^{\circ} \mathrm{C}$, fractional increases in mass-specific TEWL rates were 78 to $106 \%$ of allometric predictions. Increasing evaporative heat dissipation incurred only small metabolic costs, with the RMR of neither species ever increasing by more than $20 \%$ above thermoneutral values. Consequently, both species displayed extremely efficient evaporative cooling; maximum evaporative heat dissipation was equivalent to $515 \%$ of metabolic heat production (MHP) at $\mathrm{T}_{\mathrm{a}} \approx 566^{\circ} \mathrm{C}$ in $C$. rufigena and $452 \%$ of MHP at $\mathrm{T}_{\mathrm{a}} \approx 52{ }^{\circ} \mathrm{C}$ in $C$. tristigma. Our data reiterate that caprimulgids have evolved an efficient mechanism of evaporative cooling via gular fluttering, which minimizes metabolic heat production at high $\mathrm{T}_{\mathrm{a}}$ and reduces total heat loads. This likely aids in reducing TEWL rates and helps nightjars cope with some of the most thermally challenging conditions experienced by any bird.

\section{Keywords}

Caprimulgus rufigena, Caprimulgus tristigma, respirometry, evaporative water loss, thermoregulation, resting metabolic rate 


\section{Introduction}

Environmental temperature greatly influences the energy and water demands of an organism and thereby affects several components of fitness (McKechnie and Wolf 2010; du Plessis et al. 2012; Cunningham et al. 2013). When exposed to fluctuating air temperatures $\left(\mathrm{T}_{\mathrm{a}}\right)$ endotherms must physiologically and/or behaviourally adjust heat fluxes to maintain a body temperature $\left(\mathrm{T}_{\mathrm{b}}\right)$ set-point (Porter and Gates 1969; Tattersall et al. 2012). Because they are primarily diurnal and non-fossorial, birds living in hot, arid environments routinely experience high $T_{a}$ and intense solar radiation, resulting in operative temperatures $\left(T_{e}\right)$ well above $\mathrm{T}_{\mathrm{b}}$ (Bartholomew and Dawson 1979; Walsberg and Voss-Roberts 1983). Under such conditions, evaporative cooling is the only mechanism whereby birds can dissipate heat and avoid lethal hyperthermia (Bartholomew and Cade 1963). As $\mathrm{T}_{\mathrm{a}}$ increases above $\mathrm{T}_{\mathrm{b}}$, birds maintain sub-lethal $\mathrm{T}_{\mathrm{b}}$ through concomitant increases in total evaporative water loss (TEWL; Calder and Schmidt-Nielsen 1966; Dawson 1982). However, at very high $\mathrm{T}_{\mathrm{a}}$, TEWL can become substantial (McKechnie and Wolf 2010) and lead to rapid depletion of body water. For example, Wolf and Walsberg (1996) showed that TEWL in Verdins (Auriparus flaviceps) increased nearly 14 -fold as $\mathrm{T}_{\mathrm{a}}$ increased from 30 to $50{ }^{\circ} \mathrm{C}$, and represented $\sim 7 \%$ of body mass $\left(\mathrm{M}_{\mathrm{b}}\right)$ per hour at the latter $\mathrm{T}_{\mathrm{a}}$. In hot, arid environments where drinking water is often scarce, birds thus face a fundamental trade-off between balancing the need to evaporate large quantities of water to maintain sub-lethal $\mathrm{T}_{\mathrm{b}}$ while at the same time maintaining adequate hydration.

Whereas diurnal birds residing in hot environments can potentially replenish body water throughout the day by drinking and/or feeding on water-rich food, nocturnal species rest during the day and consequently can experience sustained periods of elevated TEWL that may lead to significant water deficits (Grant 1982). Many nocturnal taxa, such as owls (Strigidae), minimize their water requirements by occupying relatively cool, shaded sites in 
trees or cavities, thereby minimizing their need for evaporative cooling (Ligon 1968; Ligon 1969; Ganey 2004). Nightjars (Caprimulgidae), in contrast, often roost and nest on the ground in open, exposed sites where they are subjected to intense solar radiation and high $T_{e}$ that requires long periods with substantial evaporative cooling (e.g., Cowles and Dawson 1951; Dexter 1956; Weller 1958; Bartholomew et al. 1962; Steyn 1971; Grant 1982; Ingels et al. 1984). Grant (1982), for example, observed a female Lesser Nighthawk (Chordeiles acutipennis) spend almost eight hours incubating eggs in full sunlight where the black bulb temperature was $\sim 58{ }^{\circ} \mathrm{C}$. Moreover, $\mathrm{T}_{\mathrm{e}}$ is typically highest during summer months when day length is longest and periods without access to water may exceed 14 hours.

Early studies found that some caprimulgids possess highly efficient evaporative cooling by dissipating large heat loads evaporatively while exhibiting only small increases in resting metabolic rate (RMR; Bartholomew et al. 1962; Dawson and Fisher 1969; Lasiewski and Seymour 1972). However, to the best of our knowledge, no studies evaluating phenotypic variation in RMR and TEWL between seasons (e.g., summer vs. winter) or between climatically different sites (e.g., arid vs. mesic) have been conducted among caprimulgids. Most comparative research on the thermal physiology of caprimulgids has focused on hypometabolism and the use of torpor as a mechanism for energy savings (Brigham et al. 2012). Given the proclivity of caprimulgids for roosting and nesting in exposed sites that can produce significant heat stress, they present an opportunity to examine the physiological mechanisms that animals use to cope with heat stress in the most energy and water-efficient manner. Additionally, individuals of the same species can occur in a range of habitats and thus experience varying environmental temperatures (Cleere and Nurney 1998). Furthermore, some species are non-migratory and are subjected to seasonal fluctuations in $\mathrm{T}_{\mathrm{a}}$. Consequently, they represent a good model taxon for investigating phenotypic flexibility and 
intraspecific variation in physiological variables related to heat tolerance, an area where avian data are limited (e.g., Noakes et al. 2016).

Here we investigate the thermal physiology of caprimulgids exposed to high $\mathrm{T}_{\mathrm{a}}$ and ask: 1) is there a strong hyperthermic response within species and among populations when exposed to high $\mathrm{T}_{\mathrm{a}}$ ? 2) Are there pronounced changes in RMR with increasing heat stress and do these values vary among populations within a species? 3) How do rates of TEWL vary with $\mathrm{T}_{\mathrm{a}}$ and under conditions of extreme heat within species and among populations? and 4) does the thermoregulatory performance of nightjars vary intraspecifically in a manner correlated with habitat characteristics, with birds from a hot, arid site exhibiting greater heat tolerance via reduced total heat loads (e.g., low RMR), and high ratios of evaporative heat lost $[\mathrm{EHL}]$ to metabolic heat production $[\mathrm{MHP}]$ ) at any given $\mathrm{T}_{\mathrm{a}}$ compared to conspecifics from a cooler, more mesic site? We also provide preliminary data on seasonal changes in thermoregulatory responses to heat within a species.

We studied two southern African nightjars that roost and nest in sites with high diurnal heat loads (R.S. O’Connor and A.E. McKechnie unpublished data). Rufous-cheeked Nightjars (Caprimulgus rufigena) are common throughout the arid Nama Karoo and arid savanna regions of southern Africa, where they prefer open woodlands with clearings (Spottiswoode and Jackson 2005a). Rufous-cheeked Nightjars nest in natural depressions in coarse soil where shade is minimal or absent (Cleere and Nurney 1998; Spottiswoode and Jackson 2005a). Freckled Nightjars (Caprimulgus tristigma) are rupiculous breeders, laying their eggs in natural depressions on rocky outcroppings where incubating adults can experience daytime $\mathrm{T}_{\mathrm{e}}$ approaching $60^{\circ} \mathrm{C}$ (Steyn 1971; Spottiswoode and Jackson 2005b). We investigated the thermoregulatory responses of two populations of Freckled Nightjars, one from a hot, arid site that experiences predominantly winter rainfall and another from a more mesic site characterized by summer rainfall. 


\section{Materials and Methods}

\section{Study species and sites}

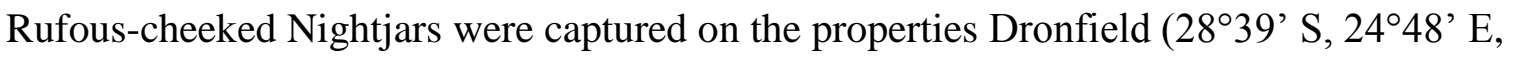
$\sim 1218 \mathrm{~m}$ ASL) and Benfontein (2848’ S, 2448’ E, 1170 m ASL) near Kimberley, South Africa during three separate periods (October 2013, October 2014 and March 2015). These field sites are $\sim 26 \mathrm{~km}$ apart and Rufous-cheeked nightjars were found in similar habitat and vegetation on both reserves, consisting of arid savannah grassland interspersed with Vachellia erioloba woodlands. During October and March, average rainfall in Kimberley is approximately $40 \mathrm{~mm}$ and average daily maximum $\mathrm{T}_{\mathrm{a}}$ is $29.7^{\circ} \mathrm{C}$ (South African Weather Service data from 2000 to present).

Freckled Nightjars were captured at two sites over two summers and one additional winter period. The first site, which represents an arid climate and where individuals belong to the subspecies C. t. lentiginosus, was on a privately owned farm in the northern Kamiesberg Mountains in the Namaqualand region of the Northern Cape province, South Africa $\left(30^{\circ} 02^{\prime}\right.$ S, $17^{\circ} 57^{\prime}$ E, 789 m ASL; same study site as described by Smit et al. 2011) during December 2013 and from December 2014 to March 2015. This site lies within the arid succulent Karoo ecoregion of western South Africa and is characterized by winter rainfall (Smit et al. 2011). Average rainfall in Namaqualand from December to March equals $8.5 \mathrm{~mm}$ and average daily maximum $\mathrm{T}_{\mathrm{a}}$ is $29.2{ }^{\circ} \mathrm{C}$ (South African Weather Service data from 2000 to present). The second summer site (subspecies C. t. granosus), which represents a mesic climate, was Ezemvelo Nature Reserve (2542’ S, 2859’ E, 1415 m ASL), near Bronkhorstspruit, Gauteng province, South Africa, with birds captured during November 2014. We captured additional individuals at Ezemvelo during the austral winter between 10 May and 11 June 2014. Ezemvelo is situated between the grassland and savannah biomes and consists of open 
grassland interspersed with rocky sandstone outcroppings and isolated woodland (Boyles et al. 2012). Average rainfall in Bronkhorstspruit during November equals $94.9 \mathrm{~mm}$ and average daily maximum $\mathrm{T}_{\mathrm{a}}$ is $28.3^{\circ} \mathrm{C}$. During May and June, average rainfall in Bronkhorstspruit equals $12.3 \mathrm{~mm}$ and average daily maximum $\mathrm{T}_{\mathrm{a}}$ is $22.5^{\circ} \mathrm{C}$ (South African Weather Service data from 2009 to present).

Rufous-cheeked Nightjars and Freckled Nightjars were captured at night by luring birds into mist nets using playback of conspecific calls or using a handheld net to catch birds resting on roads. Following capture, nightjars were held for $1-2$ nights in an enclosure $(60 \mathrm{x}$ $71 \mathrm{~cm}$ ) constructed of PVC piping and shade cloth. Individuals held for multiple nights were hand-fed a diet of wet dog food, mealworms and water, as nightjars do not readily feed in captivity (Dawson and Fisher 1969; Withers 1977). To minimize the time birds spent in captivity, all physiological measurements were conducted in the field using portable equipment.

\section{Measurements of body temperature, resting metabolic rate and evaporative water loss}

Body temperature was measured using temperature-sensitive passive integrated transponder (PIT) tags (Biomark, Boise ID, USA) injected into the peritoneal cavity. Prior to the study, a subset of 70 PIT tags was compared to thermocouple values (type T, Physitemp, Clifton, NJ, USA) in a circulating water bath at temperatures ranging from 39 to $46{ }^{\circ} \mathrm{C}$ (Whitfield et al. 2015). PIT tags deviated from thermocouple readings by $0.02 \pm 0.09$ (mean \pm SD; Whitfield et al. 2015). We recorded $\mathrm{T}_{\mathrm{b}}$ using a portable transceiver system (model 2001F-ISO, Biomark, Boise, ID, USA) connected to an external racket antenna placed within $10 \mathrm{~cm}$ of the metabolic chamber housing the study animal. PIT tag readings were logged every $15 \mathrm{sec}$ on a personal computer during respirometry trials. 
We used open flow-through respirometry to measure the rates of carbon dioxide production $\left(\dot{V}_{\mathrm{CO}_{2}} ; \mathrm{ml} \mathrm{min}^{-1}\right)$ and TEWL $\left(\mathrm{mg} \mathrm{min}^{-1}\right)$ of nightjars over a range of $\mathrm{T}_{\mathrm{a}}$ spanning $10-56^{\circ} \mathrm{C}$. Individuals were placed in metabolic chambers with volumes of $9 \mathrm{~L}$ ( $C$. tristigma and $C$. rufigena) or $4.6 \mathrm{~L}$ (C. rufigena) constructed from plastic containers. A 1-cm layer of mineral oil at the bottom of each metabolic chamber prevented evaporation from urine and faeces affecting evaporative water loss estimates. A mesh platform with spaces large enough for faeces to fall through was positioned above the mineral oil. Metabolic chambers were placed inside a modified ice chest ( 75 L) fitted with a Peltier device (model AC-162, TE Technology Inc., Traverse City MI, USA) and a custom-built controller (TC-36-25-RS486 and MP-2986) to regulate $\mathrm{T}_{\mathrm{a}}$ (typically $\pm 0.1{ }^{\circ} \mathrm{C}$ ) inside the animal chamber. Air temperature inside each metabolic chamber was measured using a thermistor probe (model TC-100, Sable Systems, Las Vegas NV, USA) inserted through a small hole in the lid and secured in place with a rubber grommet.

Atmospheric air was supplied to metabolic chambers by an air pump (model DOAP13- BN, Gast Air Pumps, Benton Harbour MI, USA) with a maximum output of $\sim 30 \mathrm{~L} \mathrm{~min}^{-}$ ${ }^{1}$. Both before entering and after exiting the pump, atmospheric air was scrubbed of water vapour by passing the air stream through columns of silica gel and drierite connected in series. Once scrubbed of water vapour, the airstream was split into two channels with one used as a baseline gas and the other directed to the animal chamber. Baseline flow rates were controlled using a needle valve (model RFU 482-1/8, Camozzi, Brescia Italy), whereas chamber flow rates were controlled with an Alicat mass-flow controller (model MCP50SLpm-D/5M, Alicat Scientific Inc., Tucson AZ, USA). To enhance the mixing of air within each chamber, a $90^{\circ}$ fitting was attached at the air inlet and directed air towards the corner of the chamber. This directed the incurrent air stream away from the air outlet port, as well as preventing incurrent air from blowing directly onto the bird. Flow rates varied 
between approximately 1 and $30 \mathrm{~L} \mathrm{~min}^{-1}$, depending on the experimental $\mathrm{T}_{\mathrm{a}}$. At lower $\mathrm{T}_{\mathrm{a}}$ values when birds were not heat stressed, we used equation 4 of $\mathrm{McNab}$ (2006) to determine the "critical" flow rate, the minimum flow rate required for the complete mixing of gases in a given chamber volume. Flow accuracy ranged from $\pm 11 \%$ at $1 \mathrm{~L} \mathrm{~min}^{-1}$ to $\leq \pm 3 \%$ at flow rates above $5 \mathrm{~L} \mathrm{~min}^{-1}$. At higher $\mathrm{T}_{\mathrm{a}}$ approaching and exceeding $\mathrm{T}_{\mathrm{b}}$, flow rates were regulated to keep chamber humidity below a dew point of $-5^{\circ} \mathrm{C}$ (relative humidity of $\approx 10 \%$ at $30{ }^{\circ} \mathrm{C}$ ). Higher flow rates (and hence lower chamber humidity) aided in keeping birds calm when exposed to high $T_{a}$ (Whitfield et al. 2015). Using Lasiewski et al. (1966) equation for estimating chamber equilibrium times indicated that at the flow rates used at $\mathrm{T}_{\mathrm{a}} \geq 30{ }^{\circ} \mathrm{C}$ mean chamber equilibrium times averaged $4.0 \pm 2.0 \mathrm{~min}$ for the $4.6 \mathrm{~L}$ chamber and $7.0 \pm 3.9 \mathrm{~min}$ for the $9 \mathrm{~L}$ chamber.

Excurrent air from the metabolic chamber and a baseline channel of incurrent air were sequentially subsampled using a MUX Flow-Multiplexer (Sable Systems, Las Vegas NV, USA) in manual mode. At the start of each set of gas exchange measurements, baseline air was first subsampled for $5 \mathrm{~min}$, followed by excurrent air from the metabolic chamber for 1015 min. Birds experienced a ramped profile of increasing $T_{a}$ (see below), and we subsampled baseline air for 3 min during each period when $\mathrm{T}_{\mathrm{a}}$ was increasing, resulting in approximately four baselines per run. The subsampled air was pulled through a $\mathrm{CO}_{2} / \mathrm{H}_{2} \mathrm{O}$ gas analyzer (model LI-840A, LI-COR, Lincoln NE, USA) and an $\mathrm{O}_{2}$ analyzer that also measured barometric pressure (FC - 10 Oxygen Analyzer, Sable Systems, Las Vegas NV, USA). Gas analysers were calibrated using the same techniques as Whitfield et al. (2015). All tubing used in the system was Bev-A-Line tubing (Thermoplastic Processes Inc., Warren, NJ, USA). Voltage outputs from analyzers were digitised using a Universal Interface (model UI-2, Sable Systems, Las Vegas NV, USA) and recorded at a sampling interval of $5 \mathrm{sec}$ using a personal computer with Expedata software (Sable Systems, Las Vegas NV, USA). 


\section{Experimental protocol}

All respirometry measurements took place during the day, the rest phase of nightjars and the time during which they naturally experience high $\mathrm{T}_{\mathrm{a}}$. Prior to being placed inside the metabolic chamber, birds were given water $(\sim 3.0-4.0 \mathrm{ml})$ with a syringe to ensure that they were well hydrated. After being placed in the chamber, birds initially spent 30 min at $\mathrm{T}_{\mathrm{a}} \approx 25$ $28{ }^{\circ} \mathrm{C}$ to habituate. Respirometry runs were separated into low $\left(\mathrm{T}_{\mathrm{a}}=10,15,20\right.$ and $\left.25^{\circ} \mathrm{C}\right)$ and high $\left(\mathrm{T}_{\mathrm{a}} \geq 30^{\circ} \mathrm{C}\right) \mathrm{T}_{\mathrm{a}}$ groups, with the experimental protocol varying depending on the $\mathrm{T}_{\mathrm{a}}$ group. At low $\mathrm{T}_{\mathrm{a}}$, nightjars were held at a $\mathrm{T}_{\mathrm{a}}$ set point for $\sim 3 \mathrm{hr}$ before $\mathrm{T}_{\mathrm{a}}$ was changed. Additionally, birds were only measured at two different $T_{a}$ values during the low $T_{a}$ runs (e.g., at 10 and $15^{\circ} \mathrm{C}$ or at 20 and $25^{\circ} \mathrm{C}$ ). Thus, for low $\mathrm{T}_{\mathrm{a}}$ runs, birds were typically in the metabolic chamber for $\sim 6 \mathrm{hr}$. Air temperature changes during low $\mathrm{T}_{\mathrm{a}}$ trials occurred in $5{ }^{\circ} \mathrm{C}$ increments with the first $\mathrm{T}_{\mathrm{a}}$ set point and direction of $\mathrm{T}_{\mathrm{a}}$ change (i.e., increase or decrease) randomised (e.g., 10 to $15^{\circ} \mathrm{C}$ or 15 to $10^{\circ} \mathrm{C}$ ). For measurements at high $\mathrm{T}_{\mathrm{a}}$, we used a ramped $\mathrm{T}_{\mathrm{a}}$ profile starting at $30{ }^{\circ} \mathrm{C}$ with subsequent $\mathrm{T}_{\mathrm{a}}$ increases to 35,38 and $40{ }^{\circ} \mathrm{C}$. Above $40{ }^{\circ} \mathrm{C}, \mathrm{T}_{\mathrm{a}}$ was increased in $2{ }^{\circ} \mathrm{C}$ increments. When chamber $\mathrm{T}_{\mathrm{a}}$ reached a stable value, birds were held at each $\mathrm{T}_{\mathrm{a}}$ set point for 10-15 min. Runs were terminated based on the same criteria used by Whitfield et al. (2015) and thus the duration an individual was kept in the chamber (average $\approx 159 \mathrm{~min}$ ) depended on their heat stress responses. Among species, nightjars lost on average $4.5 \pm 2.3 \mathrm{~g}\left(6.6 \pm 3.1 \%\right.$ of $\left.\mathrm{M}_{\mathrm{b}}\right)$ during high $\mathrm{T}_{\mathrm{a}}$ trials. The behaviour of birds during each trial was continuously monitored using an infrared camera and light, allowing us to determine whether birds were calm or exhibiting signs of distress and attempts to escape (Whitfield et al. 2015). Upon removal from the chamber, birds were immediately weighed and then given water and held in front of a fan if necessary. Once $T_{b}$ decreased to normothermic levels $\left(38-40{ }^{\circ} \mathrm{C}\right)$ birds were returned to the enclosure and then released at their site of capture that night. 
Although our measurements of EWL, RMR and $\mathrm{T}_{\mathrm{b}}$ over short periods at each $\mathrm{T}_{\mathrm{a}}$ set point could be criticized as not representing steady-state physiological data, the ramped temperature protocol we used here is in many ways analogous to the sliding cold exposure method used in summit metabolism studies (Swanson et al. 1996); as is the case when exposing birds to very low temperatures for the purposes of measuring the upper limits of cold tolerance, it is simply not practical to expose birds to $T_{a}$ far above $T_{b}$ for extended periods. Moreover, our methods follow those of several recent studies (e.g., Smith et al. 2015; Whitfield et al. 2015; McKechnie et al. 2016a;b), and so the data we present here are directly comparable to those presented by these authors.

\section{Data analyses}

Carbon dioxide and $\mathrm{H}_{2} \mathrm{O}$ traces were corrected for drift using the appropriate algorithms in Expedata. Resting values of $V_{\mathrm{CO}_{2}}$, TEWL and $\mathrm{T}_{\mathrm{b}}$ were taken as the average of the lowest, most stable 5-min period from $\mathrm{CO}_{2}$ traces at each $\mathrm{T}_{\mathrm{a}}$ set point. Data from birds that did not remain calm for $5 \mathrm{~min}$ at a $\mathrm{T}_{\mathrm{a}}$ set point were excluded from analyses. Excurrent flow rates from metabolic chambers were calculated using equation 9.3 of Lighton (2008). Rates of $\dot{V}_{\mathrm{CO}_{2}}$ and TEWL were calculated using equations 9.5 and 9.6, respectively, of Lighton (2008). To convert $\mathrm{ml} \mathrm{H}_{2} \mathrm{O}$ to $\mathrm{mg}_{2} \mathrm{O}$ we assumed $0.803 \mathrm{mg} \mathrm{H}_{2} \mathrm{O} \mathrm{mL}{ }^{-1}$ water vapour (Lighton 2008). We calculated RMR (Watts [W]) assuming $27.8 \mathrm{~kJ} \mathrm{~L} \mathrm{CO}_{2}^{-1}$ and a respiratory exchange ratio (RER) of 0.71 (i.e., lipid metabolism; Withers 1992). Evaporative heat loss (W) was calculated assuming $2.40 \mathrm{~J} \mathrm{mg} \mathrm{H}_{2} \mathrm{O}^{-1}$ (Withers 1992).

All statistical analyses were conducted in R 3.2.1 (R Core Team 2015) with all values reported as mean \pm standard deviation $(\mathrm{SD})$. We fit broken-stick regression models using the 'piecewise.linear' function in the package SiZer (Sonderegger 2012) to identify inflection 
points in our $\mathrm{T}_{\mathrm{b}}$, RMR, TEWL and EHL/MHP response variables. Data were subsequently split based on inflection points and we fitted linear mixed-effects models to the data using the packages lme4 (Bates 2015) and nlme (Pinheiro et al. 2015) with $\mathrm{T}_{\mathrm{b}}$, RMR, TEWL and EHL/MHP included as response variables and $\mathrm{T}_{\mathrm{a}}$, sex, and $\mathrm{M}_{\mathrm{b}}$ as predictor variables. Additionally, because we had data from two different field sites over both summer and winter we included site and season as predictor variables in our analysis of the data for Freckled Nightjars. One Freckled Nightjar (hereafter: bird 5599) had abnormally high RMR values between $\mathrm{T}_{\mathrm{a}} \approx 30-35^{\circ} \mathrm{C}$ and $38-52{ }^{\circ} \mathrm{C}$ and the mixed effects models at these $\mathrm{T}_{\mathrm{a}}$ ranges had Cook's distances of 2.3 and 4.3, respectively, indicating that the data for this individual were highly influential on model parameter estimates (Quin and Keough 2002). Thus, bird 5599 was ultimately excluded from the final analyses. In all models, individual identity was included as a random factor due to having repeated measurements on the same individual. Further, because we collected data in three different periods spanning two summers for Rufous-cheeked Nightjars and in two different periods over two summers for Freckled Nightjars, we included capture period as a random factor in our models to account for any variation between periods. All models were initially run as maximal models with all predictors and their interactions included. The best models were selected based on Akaike Information Criterion adjusted for small sample sizes $\left(\mathrm{AIC}_{\mathrm{c}}\right)$ using the 'dredge' function in the package MuMIn (Barton 2015). Models with $\mathrm{AIC}_{\mathrm{c}}$ values differing by less than 2 (i.e., $\left.\Delta \mathrm{AIC}_{\mathrm{c}}<2\right)$ were treated as fitting the data equally well, and consequently, the most parsimonious model was selected as the minimal adequate model (Quinn and Keough 2002; Crawley 2007). Residuals of our minimal adequate models were graphically inspected to ensure they met assumptions of normality and homogeneity of variance. Occasionally our data violated these assumptions due to outliers and we avoided transformations to conserve patterns in relationships and decided to use robust regression analyses for linear mixed 
models using the package robustlmm (Koller 2015). Because lme4 (Bates 2015) does not inherently provide $P$-values in its output (Bates 2006) we computed $95 \%$ confidence intervals (95\% CI) for all fixed effects in our minimal adequate models using the function 'confint.merMod' in lme4 (Bates 2015). We assumed a significance of less than 5\% ( $P$ < 0.05) if the $95 \%$ CI did not include the value of zero (Faraway 2006; du Prel et al. 2009). For each fixed effect in the minimal adequate model, we report the estimate and accompanying standard error (SE) and 95\% CI.

\section{Results}

\section{Body mass}

A total of 25 Rufous-cheeked Nightjars were captured over the three study periods. The average $\mathrm{M}_{\mathrm{b}}$ of males and females the morning before measurements was $52.2 \pm 4.5 \mathrm{~g}$ and $53.9 \pm 4.1 \mathrm{~g}$, respectively. Prior to measurements, average $\mathrm{M}_{\mathrm{b}}$ for summer Namaqualand Freckled Nightjars was $64.7 \pm 6.3 \mathrm{~g}(n=24)$ and for summer Ezemvelo Freckled Nightjars was $79.7 \pm 4.4 \mathrm{~g}(n=5)$, representing a significant between-population difference $(95 \% \mathrm{CI}=$ $[-17.1,-5.1])$. Freckled Nightjars at Ezemvelo were significantly $\left(F_{1,15}=22.64, P<0.001\right)$ heavier in winter $(88.1 \pm 2.8 \mathrm{~g}, n=12)$ compared to summer.

\section{Body temperature}

At $\mathrm{T}_{\mathrm{a}} \leq 15^{\circ} \mathrm{C}$, Rufous-cheeked Nightjar $\mathrm{T}_{\mathrm{b}}$ averaged $37.9 \pm 0.7{ }^{\circ} \mathrm{C}(n=5)$. At $20 \leq \mathrm{T}_{\mathrm{a}} \leq 50$

${ }^{\circ} \mathrm{C}$, the minimal adequate model only included $\mathrm{T}_{\mathrm{a}}\left(0.120 \pm 0.008{ }^{\circ} \mathrm{C}^{\circ} \mathrm{C}^{-1},[0.104,0.136]\right.$; Fig. 1a). Body temperature increased from $38.2 \pm 1.0{ }^{\circ} \mathrm{C}(n=9)$ at $\mathrm{T}_{\mathrm{a}} \approx 20{ }^{\circ} \mathrm{C}$ to $41.7 \pm 0.6{ }^{\circ} \mathrm{C}$ at $\mathrm{T}_{\mathrm{a}} \approx 50{ }^{\circ} \mathrm{C}(n=6)$. At $\mathrm{T}_{\mathrm{a}} \geq 50{ }^{\circ} \mathrm{C}, \mathrm{T}_{\mathrm{b}}$ stabilized at $41.6 \pm 0.6{ }^{\circ} \mathrm{C}(n=16$, Fig. 1a). 


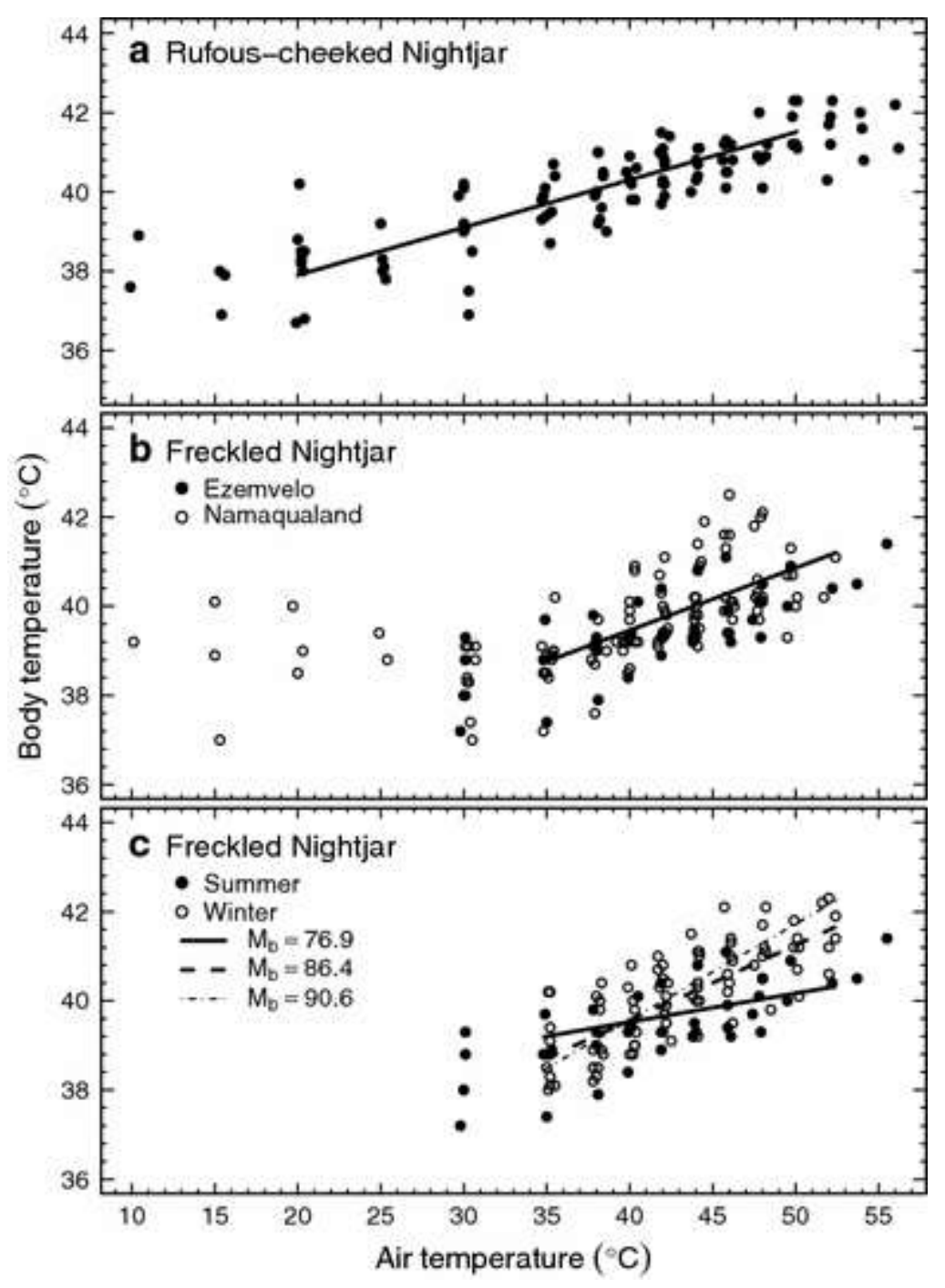

Fig. 1 Body temperature $\left(\mathrm{T}_{\mathrm{b}}\right)$ as a function of air temperature $\left(\mathrm{T}_{\mathrm{a}}\right)$ in a) Rufous-cheeked Nightjars (Caprimulgus rufigena), b) Freckled Nightjars (Caprimulgus tristigma) from a mesic (Ezemvelo) and arid (Namaqualand) site and c) Freckled Nightjars from Ezemvelo during summer and winter. The regression line in (a) is a linear model fitted to $\mathrm{T}_{\mathrm{b}}$ versus $\mathrm{T}_{\mathrm{a}}$. In (b), the regression line represents the slope from a linear model fitted to $\mathrm{T}_{\mathrm{b}}$ versus $\mathrm{T}_{\mathrm{a}}$. In (c), regression lines represent the slopes from a linear model fitted to $T_{b}$ versus the interaction between $T_{a}$ and body mass $\left(M_{b}\right)$. The $M_{b}$ values used represent cross-sections at the $10^{\text {th }}, 50^{\text {th }}$ and $90^{\text {th }}$ percentiles of the $M_{b}$ variable.

At $10 \leq \mathrm{T}_{\mathrm{a}} \leq 30^{\circ} \mathrm{C}, \mathrm{T}_{\mathrm{b}}$ of Freckled Nightjars from Namaqualand averaged $38.7 \pm 0.8$ ${ }^{\circ} \mathrm{C}(n=20$, Fig. 1b). Body temperature in Namaqualand Freckled Nightjars had a significant inflection point at $\mathrm{T}_{\mathrm{a}}=32.4{ }^{\circ} \mathrm{C}([0.107,0.263])$, above which $\mathrm{T}_{\mathrm{b}}$ increased with $\mathrm{T}_{\mathrm{a}}($ Fig. $1 \mathrm{~b})$. 
Between $\mathrm{T}_{\mathrm{a}} \approx 35$ and $52{ }^{\circ} \mathrm{C}$, there was no difference in $\mathrm{T}_{\mathrm{b}}$ between Namaqualand and summer Ezemvelo nightjars $\left(0.659 \pm 0.427^{\circ} \mathrm{C},[-0.279,1.534]\right)$, with $\mathrm{T}_{\mathrm{b}}$ increasing at $0.140 \pm 0.008$ ${ }^{\circ} \mathrm{C}{ }^{\circ} \mathrm{C}^{-1}\left([0.124,0.155]\right.$, Fig. 1b). For Namaqualand nightjars, $\mathrm{T}_{\mathrm{b}}$ increased from $38.8^{\circ} \mathrm{C}(n=$ 10) at $\mathrm{T}_{\mathrm{a}} \approx 35{ }^{\circ} \mathrm{C}$ to $40.7{ }^{\circ} \mathrm{C}$ at $\mathrm{T}_{\mathrm{a}} \approx 52{ }^{\circ} \mathrm{C}(n=2)$. Similarly, between $\mathrm{T}_{\mathrm{a}} \approx 35$ and $52{ }^{\circ} \mathrm{C}$, summer Ezemvelo nightjar $\mathrm{T}_{\mathrm{b}}$ increased from $38.7^{\circ} \mathrm{C}(n=4)$ to $40.5^{\circ} \mathrm{C}(n=2)$.

Between $\mathrm{T}_{\mathrm{a}} \approx 35$ and $52^{\circ} \mathrm{C}$, the minimal adequate model explaining $\mathrm{T}_{\mathrm{b}}$ among Ezemvelo Freckled Nightjars included $\mathrm{T}_{\mathrm{a}}\left(F_{1,95}=388.21, P<0.0001\right), \mathrm{M}_{\mathrm{b}}\left(F_{1,15}=0.56, P=\right.$ $0.464)$ and the interaction between $\mathrm{T}_{\mathrm{a}}$ and $\mathrm{M}_{\mathrm{b}}\left(F_{1,95}=34.74, P<0.0001 ;\right.$ Fig $\left.1 \mathrm{c}\right)$. At $35 \leq \mathrm{T}_{\mathrm{a}} \leq$ $52{ }^{\circ} \mathrm{C}, \mathrm{T}_{\mathrm{b}}$ of Ezemvelo Freckled Nightjars did not differ between summer and winter $\left(F_{1,15}=\right.$ 2.31, $P=0.150 ;$ Fig 1c $)$, with mean winter $\mathrm{T}_{\mathrm{b}}=40.1 \pm 1.1{ }^{\circ} \mathrm{C}(n=83)$ and summer $\mathrm{T}_{\mathrm{b}}=39.5$ $\pm 0.8^{\circ} \mathrm{C}(n=31)$.

\section{Resting metabolic rate}

At $10 \leq \mathrm{T}_{\mathrm{a}} \leq 35^{\circ} \mathrm{C}$, the minimal adequate model for RMR in Rufous-cheeked Nightjars only included $\mathrm{T}_{\mathrm{a}}\left(-0.013 \pm 0.002 \mathrm{~W}^{\circ} \mathrm{C}^{-1},[-0.016,-0.010]\right.$; Fig. 2a). Resting metabolic rate decreased from $0.52 \pm 0.1 \mathrm{~W}$ at $\mathrm{T}_{\mathrm{a}} \approx 10{ }^{\circ} \mathrm{C}(n=3)$ to $0.30 \pm 0.06 \mathrm{~W}$ at $\mathrm{T}_{\mathrm{a}} \approx 35^{\circ} \mathrm{C}(n=15)$. A significant inflection point in $\mathrm{RMR}$ occurred at $\mathrm{T}_{\mathrm{a}}=35.8^{\circ} \mathrm{C}([0.010,0.020])$, which we interpret as the lower critical limit of thermoneutrality $\left(\mathrm{T}_{\mathrm{lc}}\right)$. At $38 \leq \mathrm{T}_{\mathrm{a}} \leq 50{ }^{\circ} \mathrm{C}$, the minimal adequate model only included sex ([-0.133, -0.056]), with females having a higher RMR $(0.375 \pm 0.051 \mathrm{~W}, n=12)$ than males $(0.284 \pm 0.034 \mathrm{~W}, n=70)$. At $\mathrm{T}_{\mathrm{a}}$ between 38 and 50 ${ }^{\circ} \mathrm{C}, \mathrm{RMR}$ did not vary with $\mathrm{T}_{\mathrm{a}}\left(0.0009 \pm 0.0006 \mathrm{~W}^{\circ} \mathrm{C}^{-1},[-0.0003,0.002]\right.$; Fig. 2a). 


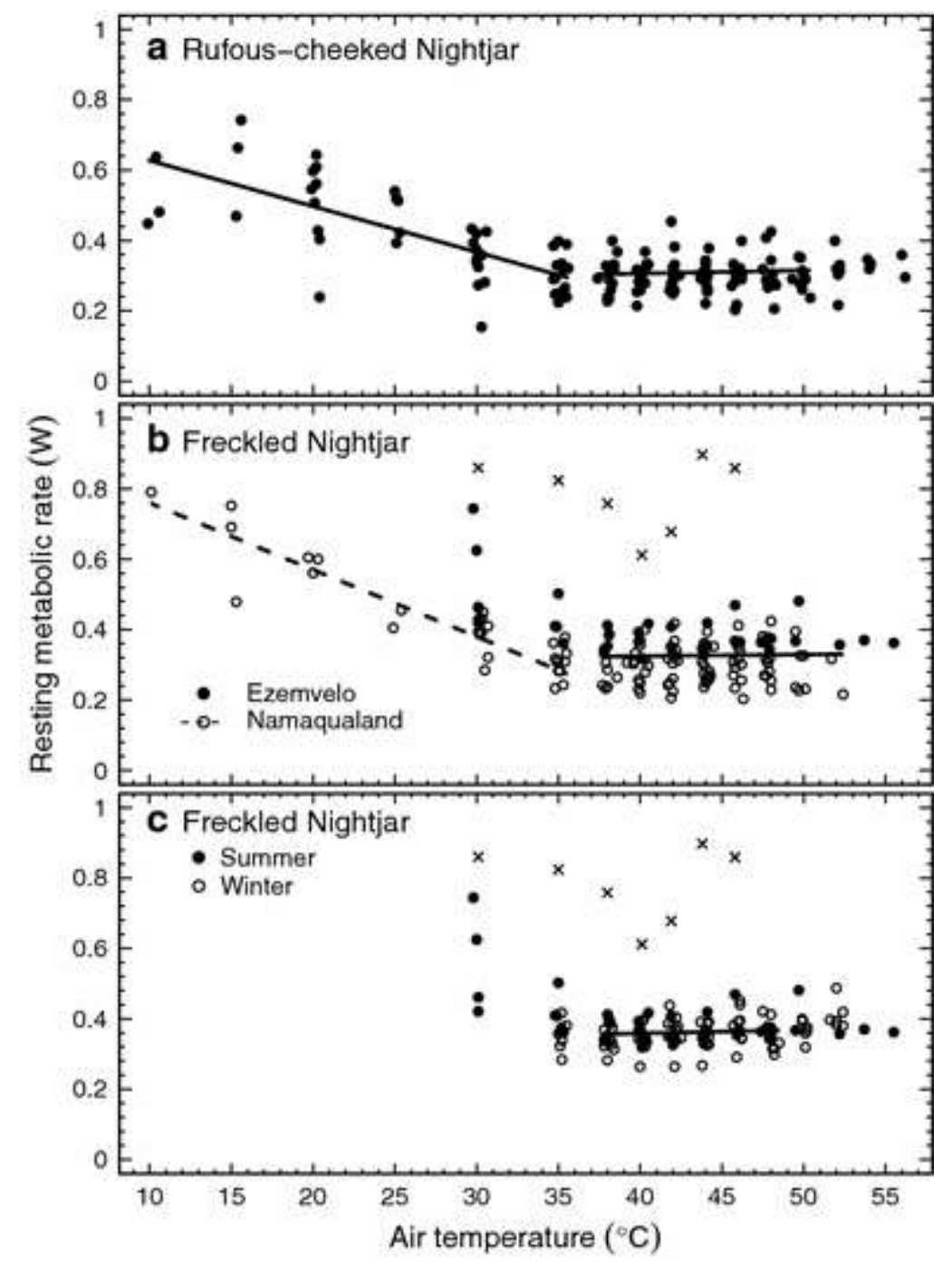

Fig. 2 Resting metabolic rate (RMR) as a function of air temperature $\left(T_{a}\right)$ in a) Rufous-cheeked Nightjars (Caprimulgus rufigena), b) Freckled Nightjars (Caprimulgus tristigma) from a mesic (Ezemvelo) and arid (Namaqualand) site and c) Freckled Nightjars from Ezemvelo during summer and winter. In (a), the regression lines between $\mathrm{T}_{\mathrm{a}} \approx 10-35^{\circ} \mathrm{C}$ and $38-50{ }^{\circ} \mathrm{C}$ are from two linear models fitted to RMR versus $\mathrm{T}_{\mathrm{a}}$. In (b), the regression line between $\mathrm{T}_{\mathrm{a}} \approx 10-35^{\circ} \mathrm{C}$ is from a linear model fitted to RMR versus $\mathrm{T}_{\mathrm{a}}$ in Namaqualand birds and the horizontal regression line is from a linear model fitted to RMR versus $\mathrm{T}_{\mathrm{a}}$. In (c), the regression line is from a linear model fitted to RMR versus $\mathrm{T}_{\mathrm{a}}$. The outlier bird 5599 is marked with an $\mathrm{X}$ in panels (b) and (c).

For Namaqualand Freckled Nightjars, the minimal adequate model for RMR at $10 \leq$ $\mathrm{T}_{\mathrm{a}} \leq 35^{\circ} \mathrm{C}$ included $\mathrm{T}_{\mathrm{a}}\left(-0.020 \pm 0.001 \mathrm{~W}^{\circ} \mathrm{C}^{-1},[-0.022,-0.018]\right)$ and $\mathrm{M}_{\mathrm{b}}\left(0.009 \pm 0.002 \mathrm{~W} \mathrm{~g}^{-}\right.$ $\left.{ }^{1},[0.005,0.012]\right)$. At $\mathrm{T}_{\mathrm{a}} \approx 10^{\circ} \mathrm{C}, \mathrm{RMR}$ in Namaqualand Freckled nightjars was $0.79 \mathrm{~W}$ and 
decreased to $0.31 \pm 0.04 \mathrm{~W}(n=11)$ at $\mathrm{T}_{\mathrm{a}} \approx 35^{\circ} \mathrm{C}$. An inflection point in RMR for Namaqualand Freckled Nightjars occurred at $\mathrm{T}_{\mathrm{a}}=35.1{ }^{\circ} \mathrm{C}([0.013,0.025])$ and for summer Ezemvelo Freckled Nightjars at $\mathrm{T}_{\mathrm{a}}=36.6^{\circ} \mathrm{C}([0.009,1.104]$; Fig. $2 \mathrm{~b})$, which we interpret as the $\mathrm{T}_{\mathrm{lc}}$.

At $38 \leq \mathrm{T}_{\mathrm{a}} \leq 52{ }^{\circ} \mathrm{C}$, the minimal adequate model explaining variation in RMR between Ezemvelo and Namaqualand Freckled Nightjars only included $\mathrm{M}_{\mathrm{b}}(0.005 \pm 0.001 \mathrm{~W}$ $\left.\mathrm{g}^{-1},[0.003,0.008]\right)$. Over the same $\mathrm{T}_{\mathrm{a}}$ range, RMR remained stable with increasing $\mathrm{T}_{\mathrm{a}}(0.0005$ $\pm 0.0008 \mathrm{~W}^{\circ} \mathrm{C}^{-1},[-0.001,0.002]$; Fig $\left.2 \mathrm{~b}\right)$, averaging $0.37 \pm 0.04 \mathrm{~W}(n=27)$ in Ezemvelo Freckled Nightjars and $0.30 \pm 0.06 \mathrm{~W}(n=81)$ in Namaqualand nightjars. When the data were analyzed using mass-specific values between $\mathrm{T}_{\mathrm{a}} \approx 38$ and $52{ }^{\circ} \mathrm{C}, \mathrm{T}_{\mathrm{a}}(0.008 \pm 0.011 \mathrm{~mW}$ $\left.\mathrm{g}^{-1}{ }^{\circ} \mathrm{C}^{-1},[-0.014,0.030]\right)$ and site $\left(0.095 \pm 0.326 \mathrm{~mW} \mathrm{~g}^{-1},[-0.791,0.676]\right)$ remained nonsignificant. Mass-specific RMR between $\mathrm{T}_{\mathrm{a}} \approx 38$ and $52{ }^{\circ} \mathrm{C}$ for Namaqualand nightjars was $4.48 \pm 0.70 \mathrm{~mW} \mathrm{~g}^{-1}$ and for summer Ezemvelo nightjars $4.70 \pm 0.42 \mathrm{~mW} \mathrm{~g}^{-1}$.

At $38 \leq \mathrm{T}_{\mathrm{a}} \leq 48{ }^{\circ} \mathrm{C}$, the null model emerged as the top model for RMR in summer and winter Ezemvelo Freckled Nightjars. Over this $\mathrm{T}_{\mathrm{a}}$ range, RMR did not vary with $\mathrm{T}_{\mathrm{a}}(0.0009 \pm$ $0.0007 \mathrm{~W}^{\circ} \mathrm{C}^{-1},[-0.0004,0.002] ;$ Fig. $\left.2 \mathrm{c}\right)$, nor did it differ between seasons $([-0.055,0.022]$; Fig. 2c), with mean winter $\mathrm{RMR}=0.35 \pm 0.04 \mathrm{~W}(n=61)$ and mean summer $\mathrm{RMR}=0.37 \pm$ $0.03 \mathrm{~W}(n=24)$. Winter Ezemvelo birds displayed a shallow inflection point in $\mathrm{RMR}$ at $\mathrm{T}_{\mathrm{a}}=$ $49.5{ }^{\circ} \mathrm{C}([-0.004,0.061])$, with RMR increasing to $0.41 \pm 0.04 \mathrm{~W}(n=6)$ at $\mathrm{T}_{\mathrm{a}} \approx 52{ }^{\circ} \mathrm{C}($ Fig. 2c). Mass-specific RMR between $\mathrm{T}_{\mathrm{a}} \approx 38$ and $48{ }^{\circ} \mathrm{C}$ was significantly higher in summer than winter among Ezemvelo birds $\left(F_{1,15}=12.463, P=0.003\right)$, with mass-specific RMR values of $4.68 \pm 0.36 \mathrm{~mW} \mathrm{~g}^{-1}$ and $4.0 \pm 0.44 \mathrm{~mW} \mathrm{~g}^{-1}$, respectively. 


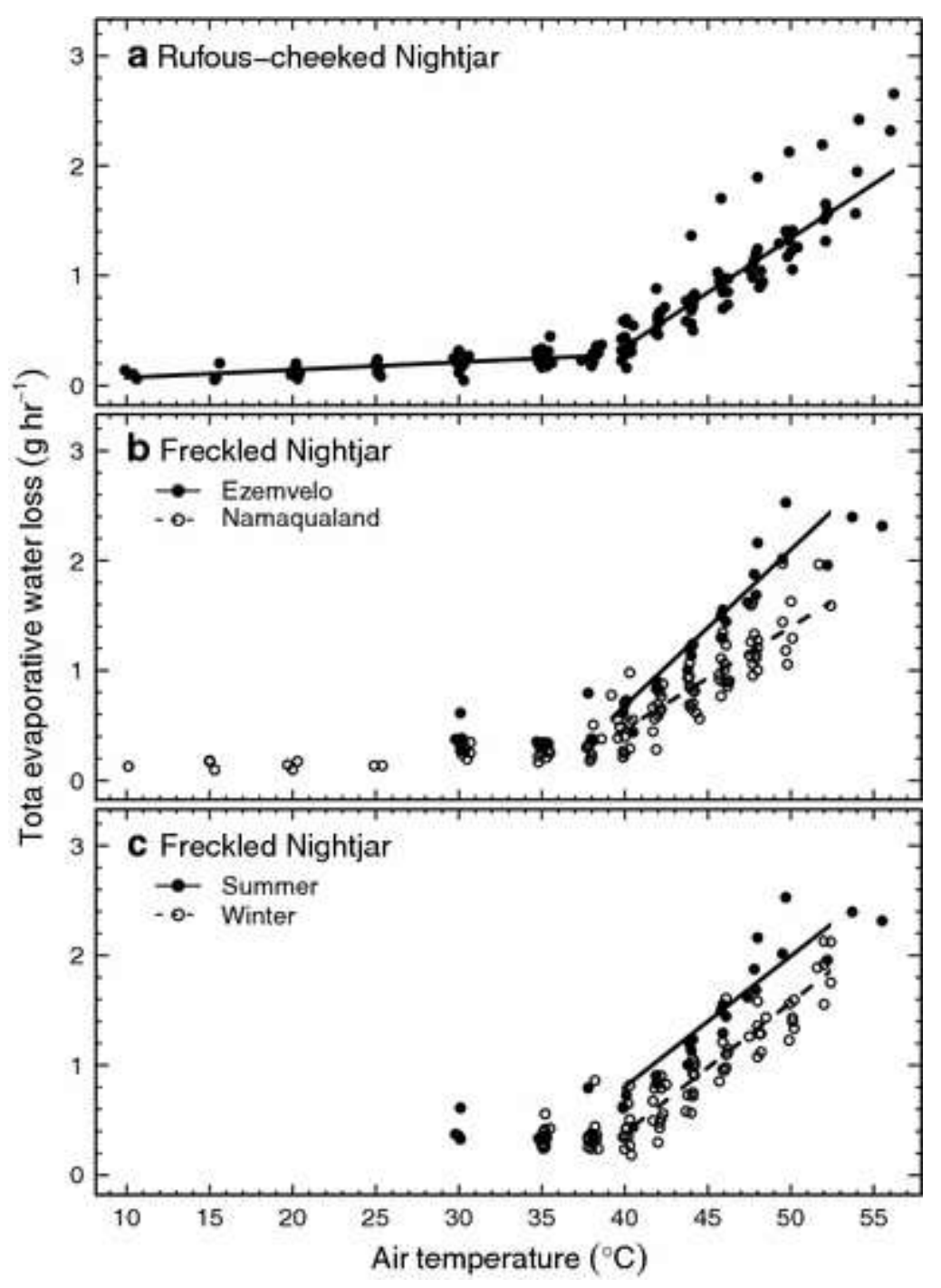

Fig. 3 Total evaporative water loss (TEWL) as a function of air temperature $\left(T_{a}\right)$ in a) Rufous-cheeked Nightjars (Caprimulgus rufigena), b) Freckled Nightjars (Caprimulgus tristigma) from a mesic (Ezemvelo) and arid (Namaqualand) site and c) Freckled Nightjars from Ezemvelo during summer and winter. In (a), the regression lines between $\mathrm{T}_{\mathrm{a}} \approx 10-38{ }^{\circ} \mathrm{C}$ and $40-56{ }^{\circ} \mathrm{C}$ are from two linear models fitted to TEWL versus $\mathrm{T}_{\mathrm{a}}$. In (b), regression lines are from a linear model fitted to TEWL versus the interaction between site and $\mathrm{T}_{\mathrm{a}}$. In (c), regression lines represent the common regression slope from a linear model fitted to TEWL versus season with $\mathrm{T}_{\mathrm{a}}$ as a covariate. 


\section{Evaporative water loss}

Between $\mathrm{T}_{\mathrm{a}} \approx 10$ and $38{ }^{\circ} \mathrm{C}$, the minimal adequate model for TEWL in Rufous-cheeked Nightjars only included $\mathrm{T}_{\mathrm{a}}\left(0.007 \pm 0.001 \mathrm{~g} \mathrm{H}_{2} \mathrm{O} \mathrm{hr}{ }^{-1}{ }^{\circ} \mathrm{C}^{-1},[0.005,0.009]\right.$; Fig. 3a). At $\mathrm{T}_{\mathrm{a}} \approx 10$ ${ }^{\circ} \mathrm{C}$, TEWL averaged $0.10 \pm 0.04 \mathrm{~g} \mathrm{H}_{2} \mathrm{O} \mathrm{hr}{ }^{-1}(n=3)$ and increased to $0.28 \pm 0.05 \mathrm{~g} \mathrm{H}_{2} \mathrm{O} \mathrm{hr}^{-1}$ at $\mathrm{T}_{\mathrm{a}} \approx 38^{\circ} \mathrm{C}(n=13)$. A significant inflection point in TEWL occurred at $\mathrm{T}_{\mathrm{a}}=39.5^{\circ} \mathrm{C}([0.088$, 0.119]), above which TEWL increased rapidly (Fig. 3a). Between $\mathrm{T}_{\mathrm{a}} \approx 40$ and $56{ }^{\circ} \mathrm{C}$, the minimal adequate model for TEWL only included $\mathrm{T}_{\mathrm{a}}\left(0.099 \mathrm{~g} \mathrm{H}_{2} \mathrm{O} \mathrm{hr}^{-1}{ }^{\circ} \mathrm{C}^{-1},[0.093,0.105]\right.$; Fig. 3a), with TEWL reaching $2.49 \pm 0.24 \mathrm{~g} \mathrm{H}_{2} \mathrm{O} \mathrm{hr}{ }^{-1}(n=2)$ at $\mathrm{T}_{\mathrm{a}} \approx 56^{\circ} \mathrm{C}$.

Total evaporative water loss for Freckled Nightjars from Namaqualand remained low and stable at $10 \leq \mathrm{T}_{\mathrm{a}} \leq 25^{\circ} \mathrm{C}$, averaging $0.14 \pm 0.03 \mathrm{~g} \mathrm{H}_{2} \mathrm{O} \mathrm{hr}{ }^{-1}(n=9)$. Significant inflection points in TEWL occurred at $\mathrm{T}_{\mathrm{a}}=38.3{ }^{\circ} \mathrm{C}([0.074,0.110])$ for Namaqualand nightjars and at $\mathrm{T}_{\mathrm{a}}=37.0^{\circ} \mathrm{C}([0.091,0.183])$ for summer Ezemvelo nightjars, above which TEWL increased rapidly (Fig 3b).

The minimal adequate model explaining summer TEWL at $40 \leq \mathrm{T}_{\mathrm{a}} \leq 52{ }^{\circ} \mathrm{C}$ in Ezemvelo and Namaqualand Freckled Nightjars included $\mathrm{T}_{\mathrm{a}}\left(0.142 \pm 0.010 \mathrm{~g} \mathrm{H}_{2} \mathrm{O} \mathrm{hr}^{-1}{ }^{\circ} \mathrm{C}\right.$, $[0.123,0.163])$, site $\left(1.747 \pm 0.523 \mathrm{~g} \mathrm{H}_{2} \mathrm{O} \mathrm{hr}{ }^{-1},[0.742,2.802]\right)$ and the interaction between $\mathrm{T}_{\mathrm{a}}$ and site $\left(-0.049 \pm 0.011 \mathrm{~g} \mathrm{H}_{2} \mathrm{O} \mathrm{hr}{ }^{-1}{ }^{\circ} \mathrm{C},[-0.072,-0.026]\right.$; Fig. 3b). The slope of the interaction between $\mathrm{T}_{\mathrm{a}}$ and site for Namaqualand birds was $0.093 \mathrm{~g} \mathrm{H}_{2} \mathrm{O} \mathrm{hr}{ }^{-1}{ }^{\circ} \mathrm{C}^{-1}$ and for Ezemvelo birds was $0.142 \mathrm{~g} \mathrm{H}_{2} \mathrm{O} \mathrm{hr}{ }^{-1}{ }^{\circ} \mathrm{C}^{-1}$. At $\mathrm{T}_{\mathrm{a}}=40-52{ }^{\circ} \mathrm{C}$, average summer TEWL was lower in Namaqualand nightjars $\left(0.91 \pm 0.38 \mathrm{~g} \mathrm{H}_{2} \mathrm{O} \mathrm{hr}^{-1}, n=73\right)$ compared to Ezemvelo nightjars $\left(1.31 \pm 0.55 \mathrm{~g} \mathrm{H}_{2} \mathrm{O} \mathrm{hr}{ }^{-1}, n=23\right)$. For Namaqualand Freckled Nightjars, TEWL $=0.13 \mathrm{~g} \mathrm{H}_{2} \mathrm{O}$ $\mathrm{hr}^{-1}$ at $10{ }^{\circ} \mathrm{C}$, increasing to $1.78 \pm 0.27 \mathrm{~g} \mathrm{H}_{2} \mathrm{O} \mathrm{hr}{ }^{-1}(n=2)$ at $52{ }^{\circ} \mathrm{C}$. For summer Ezemvelo Freckled Nightjars, TEWL $=0.42 \pm 0.13 \mathrm{~g} \mathrm{H}_{2} \mathrm{O} \mathrm{hr}{ }^{-1}(n=4)$ at $\mathrm{T}_{\mathrm{a}} \approx 30{ }^{\circ} \mathrm{C}$, increasing to 2.32 $\mathrm{g} \mathrm{H}_{2} \mathrm{O} \mathrm{hr}{ }^{-1}$ at $56{ }^{\circ} \mathrm{C}$. Between $40 \leq \mathrm{T}_{\mathrm{a}} \leq 52{ }^{\circ} \mathrm{C}$, the minimal adequate model for mass-specific 
TEWL included $\mathrm{T}_{\mathrm{a}}\left(1.488 \pm 0.072 \mathrm{mg} \mathrm{H}_{2} \mathrm{O} \mathrm{g}^{-1} \mathrm{hr}^{-1},[1.349,1.636]\right)$ and site $([-5.164,-1.096])$, with mass-specific TEWL averaging $13.51 \pm 5.44 \mathrm{mg} \mathrm{H}_{2} \mathrm{O} \mathrm{g}^{-1} \mathrm{hr}^{-1}$ in Namaqualand birds and $16.41 \pm 6.85 \mathrm{mg} \mathrm{H}_{2} \mathrm{O} \mathrm{g}^{-1} \mathrm{hr}^{-1}$ in summer Ezemvelo birds.

Among Ezemvelo Freckled Nightjars, TEWL at $\mathrm{T}_{\mathrm{a}}<40^{\circ} \mathrm{C}$ remained low and stable in both winter and summer (Fig. 3c). There was a significant inflection point in winter TEWL at $\mathrm{T}_{\mathrm{a}}=39.9^{\circ} \mathrm{C}([0.078,0.151])$, above which TEWL increased rapidly (Fig 3c). The minimal adequate model for TEWL among Ezemvelo Freckled Nightjars at $\mathrm{T}_{\mathrm{a}} \approx 40-52{ }^{\circ} \mathrm{C}$ included $\mathrm{Ta}\left(0.119 \pm 0.004 \mathrm{~g} \mathrm{H}_{2} \mathrm{O} \mathrm{hr}^{-1}{ }^{\circ} \mathrm{C}, F_{1,67}=781.515, P<0.0001\right)$ and season $\left(F_{1,15}=24.665, P<\right.$ 0.001). Mean TEWL was higher in summer $\left(1.31 \pm 0.55 \mathrm{~g} \mathrm{H}_{2} \mathrm{O} \mathrm{hr}{ }^{-1}, n=23\right)$ than winter $(0.98$ $\pm 0.48 \mathrm{~g} \mathrm{H}_{2} \mathrm{O} \mathrm{hr}{ }^{-1}, n=62$, Fig. 3c). Winter TEWL $=0.35 \pm 0.10 \mathrm{~g} \mathrm{H}_{2} \mathrm{O} \mathrm{hr}{ }^{-1}$ at $\mathrm{T}_{\mathrm{a}} \approx 35^{\circ} \mathrm{C}(n=$ 10) and increased to $1.90 \pm 0.22 \mathrm{~g} \mathrm{H}_{2} \mathrm{O} \mathrm{hr}^{-1}$ at $52^{\circ} \mathrm{C}(n=6)$. The minimal adequate model for mass-specific TEWL between $\mathrm{T}_{\mathrm{a}} \approx 40$ and $52{ }^{\circ} \mathrm{C}$ included $\mathrm{T}_{\mathrm{a}}\left(F_{1,66}=811.814, P<0.0001\right)$, season $\left(F_{1,15}=42.272, P<0.0001\right)$ and the interaction between $\mathrm{T}_{\mathrm{a}}$ and season $\left(F_{1,66}=14.552\right.$, $P<0.001)$. Mass-specific TEWL averaged $11.21 \pm 5.60 \mathrm{mg} \mathrm{H}_{2} \mathrm{O} \mathrm{g}^{-1} \mathrm{hr}^{-1}$ for winter birds and $16.41 \pm 6.85 \mathrm{mg} \mathrm{H}_{2} \mathrm{O} \mathrm{g}^{-1} \mathrm{hr}^{-1}$ in summer birds between $\mathrm{T}_{\mathrm{a}} \approx 40-52{ }^{\circ} \mathrm{C}$.

\section{Ratio of evaporative heat loss to metabolic heat production}

In Rufous-cheeked Nightjars, at $\mathrm{T}_{\mathrm{a}}$ below thermoneutrality EHL/MHP increased significantly and linearly with $\mathrm{T}_{\mathrm{a}}(0.020 \pm 0.002,[0.016,0.023]$; Fig. $4 \mathrm{a})$ from $0.13 \pm 0.07$ at $10{ }^{\circ} \mathrm{C}(n=3)$ to $0.63 \pm 0.10$ at $38^{\circ} \mathrm{C}(n=13)$. The slope of EHL/MHP versus $\mathrm{T}_{\mathrm{a}}$ changed significantly at $\mathrm{T}_{\mathrm{a}}$ $=39.2{ }^{\circ} \mathrm{C}([0.176,0.234])$, corresponding to rapid increases in TEWL. Between $\mathrm{T}_{\mathrm{a}} \approx 40$ and $56{ }^{\circ} \mathrm{C}$, the minimal adequate model for EHL/MHP only included $\mathrm{T}_{\mathrm{a}}(0.214 \pm 0.009,[0.196$, 0.233]; Fig. 4a). At $\mathrm{T}_{\mathrm{a}} \geq 44{ }^{\circ} \mathrm{C}$, all birds were dissipating more than $100 \%$ of MHP through evaporation. At $\mathrm{T}_{\mathrm{a}} \approx 56{ }^{\circ} \mathrm{C}$, mean EHL/MHP $=5.15 \pm 1.2(n=2$; Fig. 4a). 


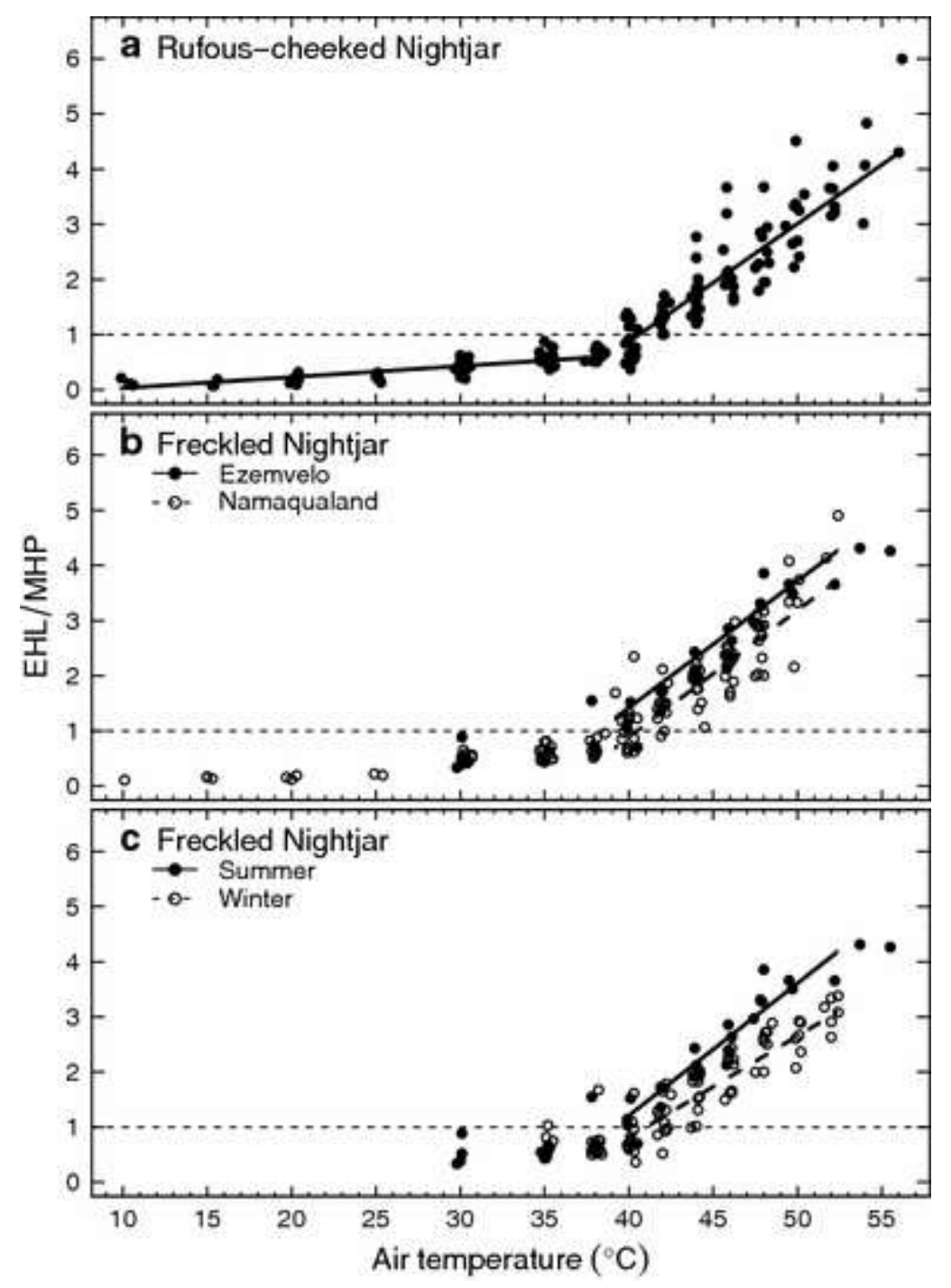

Fig. 4 The ratio of evaporative heat loss to metabolic heat production (EHL/MHP) as a function of air temperature $\left(\mathrm{T}_{\mathrm{a}}\right.$ ) in a) Rufous-cheeked Nightjars (Caprimulgus rufigena), b) Freckled Nightjars (Caprimulgus tristigma) from a mesic (Ezemvelo) and arid (Namaqualand) site and c) Freckled Nightjars from Ezemvelo during summer and winter. In (a), the regression lines are from two linear models fitted to EHL/MHP versus $\mathrm{T}_{\mathrm{a}}$ between $\mathrm{T}_{\mathrm{a}} \approx 10-38{ }^{\circ} \mathrm{C}$ and $40-56{ }^{\circ} \mathrm{C}$. In (b), regression lines represent the common slope from a linear model fitted to EHL/MHP versus site with $\mathrm{T}_{\mathrm{a}}$ as a covariate. In (c), regression lines are from a linear model fitted to EHL/MHP versus the interaction between season and $\mathrm{T}_{\mathrm{a}}$.

In Freckled Nightjars at our Namaqualand study site, EHL/MHP remained low between $\mathrm{T}_{\mathrm{a}} \approx 10$ and $25^{\circ} \mathrm{C}$, with EHL/MHP $=0.11$ at $\mathrm{T}_{\mathrm{a}} \approx 10{ }^{\circ} \mathrm{C}$ and $0.21 \pm 0.02$ at $\mathrm{T}_{\mathrm{a}} \approx 25$ 
${ }^{\circ} \mathrm{C}(n=2)$. Rapid increases in EHL/MHP occurred above $\mathrm{T}_{\mathrm{a}}=38.5^{\circ} \mathrm{C}([0.165,0.269])$ and above $\mathrm{T}_{\mathrm{a}}=36.8^{\circ} \mathrm{C}([0.138,0.286])$ in Namaqualand and summer Ezemzelo Freckled Nightjars, respectively. At $40 \leq \mathrm{T}_{\mathrm{a}} \leq 52^{\circ} \mathrm{C}$, the minimal adequate model for EHL/MHP included $\mathrm{T}_{\mathrm{a}}(0.230 \pm 0.008,[0.213,0.246])$ and site $(-0.535 \pm 0.190,[-0.907,-0.163])$, with Ezemvelo nightjars having higher EHL/MHP values (Fig 4b). In Namaqualand Freckled Nightjars, maximum EHL/MHP was $4.5 \pm 0.5$ at $\mathrm{T}_{\mathrm{a}} \approx 52{ }^{\circ} \mathrm{C}(n=2)$.

For winter Ezemvelo Freckled Nightjars, EHL/MHP increased rapidly above $\mathrm{T}_{\mathrm{a}}=$ $39.8{ }^{\circ} \mathrm{C}([0.118,0.248]$; Fig. $4 \mathrm{c})$. The minimal adequate model for EHL/MHP between $\mathrm{T}_{\mathrm{a}} \approx$ 40 and $52{ }^{\circ} \mathrm{C}$ included season $\left(F_{1,15}=24.568, P<0.001\right), \mathrm{T}_{\mathrm{a}}\left(F_{1,66}=922.255, P<0.0001\right)$ and the interaction between season and $\mathrm{T}_{\mathrm{a}}\left(F_{1,66}=12.597, P<0.001\right.$; Fig. $\left.4 \mathrm{c}\right)$. The slope of the interaction between $\mathrm{T}_{\mathrm{a}}$ and season for winter Ezemvelo birds was $0.184{ }^{\circ} \mathrm{C}^{-1}$ and for summer Ezemvelo birds was $0.240{ }^{\circ} \mathrm{C}^{-1}$.

\section{Discussion}

Rufous-cheeked Nightjars and Freckled Nightjars exhibited a pronounced capacity to tolerate high heat loads and were able to maintain $T_{b}$ far below $T_{a}$. Moreover, even at the highest $T_{a}$ to which they were exposed, all individuals of both species maintained $\mathrm{T}_{\mathrm{b}}$ below $\sim 42.5^{\circ} \mathrm{C}$. At $\mathrm{T}_{\mathrm{a}}$ values above $37.0-39.9^{\circ} \mathrm{C}$, TEWL increased rapidly with increasing $\mathrm{T}_{\mathrm{a}}$ whereas $\mathrm{RMR}$ remained stable, resulting in efficient evaporative cooling (i.e., large increases in EHL with small increases in MHP at a given $\mathrm{T}_{\mathrm{a}}$ ). The maximum evaporative cooling capacity of both species exceeds that of most birds investigated to date. In the following discussion, we compare the thermoregulatory patterns and evaporative cooling efficiency at high $\mathrm{T}_{\mathrm{a}}$ in the two nightjar species we studied with data from other caprimulgids. We subsequently place 
our results in a broader context and compare the physiological responses of our study species at high $\mathrm{T}_{\mathrm{a}}$ to those of other avian taxa studied under similar conditions.

\section{Body temperature}

Both nightjar species displayed relatively labile $T_{b}$ that was positively related to $T_{a}$. Qualitatively similar patterns of $\mathrm{T}_{\mathrm{b}}$ lability have been documented in Common Nighthawks (Chordeiles minor; Lasiewski and Dawson 1964), Spotted Nightjars (Dawson and Fisher 1969) and Poorwills (Phalaenoptilus nuttallii; Lasiewski and Seymour 1972). Increases in $\mathrm{T}_{\mathrm{b}}$ at moderate to high $\mathrm{T}_{\mathrm{a}}$ appears common among birds and has been observed in phylogenetically diverse taxa (Weathers and Schoenbaechler 1976; Weathers 1981; Tieleman and Williams 1999). Increases in $\mathrm{T}_{\mathrm{b}}$ at high $\mathrm{T}_{\mathrm{a}}$ should enhance a bird's water economy in hot environments through a more favourable $T_{b}-T_{a}$ gradient, thereby increasing the potential for dry heat loss when $T_{a}<T_{b}$ and decreasing the potential for dry heat gain when $T_{a}>T_{b}$ (Tieleman and Williams 1999). Additionally, heat stored internally during the day can be dissipated later through non-evaporative pathways when $\mathrm{T}_{\mathrm{a}}$ is conducive (Weathers and Schoenbaechler 1976; Weathers 1981; Tieleman and Williams 1999). For example, through heat stored in body tissue, Rufous-cheeked Nightjars could have saved a maximum of 128 mg $\mathrm{H}_{2} \mathrm{O}$ at $\mathrm{T}_{\mathrm{a}} \approx 50{ }^{\circ} \mathrm{C}$ by allowing $\mathrm{T}_{\mathrm{b}}$ to increase $1.7{ }^{\circ} \mathrm{C}$ relative to $\mathrm{T}_{\mathrm{b}}$ at $\mathrm{T}_{\mathrm{a}} \approx 38^{\circ} \mathrm{C}$. Similarly, Namaqualand Freckled Nightjars could have saved $139 \mathrm{mg} \mathrm{H}_{2} \mathrm{O}$ at $\mathrm{T}_{\mathrm{a}} \approx 50{ }^{\circ} \mathrm{C}$ by allowing $\mathrm{T}_{\mathrm{b}}$ to increase $1.5^{\circ} \mathrm{C}$ relative to $\mathrm{T}_{\mathrm{b}}$ at $\mathrm{T}_{\mathrm{a}} \approx 38{ }^{\circ} \mathrm{C}$. Thus, for nocturnal species like nightjars, where during the day prolonged periods of high rates of evaporative water loss are common, a labile $\mathrm{T}_{\mathrm{b}}$ would presumably contribute to the conservation of body water and avoidance of dehydration. 
Both Rufous-cheeked Nightjars and Freckled Nightjars increased $T_{b}$ as $T_{a}$ increased within the TNZ without concomitant increases in metabolic heat production, a phenomenon previously reported for a number of avian species (Weathers and Schoenbaechler 1976, Weathers 1981, Tieleman and Williams 1999). However, given the thermal sensitivity of biochemical reaction rates, one might expect an increase in metabolic rate with $\mathrm{T}_{\mathrm{b}}$ due to $\mathrm{a}$ $\mathrm{Q}_{10}$ effect. For example, assuming a $\mathrm{Q}_{10}$ of 2.5 , we would have expected mean RMR in Rufous-cheeked Nightjars to increase from $0.299 \mathrm{~W}$ at $\mathrm{T}_{\mathrm{a}}=38{ }^{\circ} \mathrm{C}$ to $0.350 \mathrm{~W}$ at $\mathrm{T}_{\mathrm{a}}=50{ }^{\circ} \mathrm{C}$ when mean $\mathrm{T}_{\mathrm{b}}$ increased from 40 to $41.7^{\circ} \mathrm{C}$. Yet, at $\mathrm{T}_{\mathrm{a}}=50{ }^{\circ} \mathrm{C}$, mean $\mathrm{RMR}=0.296 \mathrm{~W}$. Traditionally, $\mathrm{Q}_{10}$ has been used to describe relationships between metabolic rate and temperature in ectotherms and some authors have argued whether $\mathrm{Q}_{10}$ effects should be applied to endotherms (Snyder and Nestler 1990; Heldmaier and Ruf 1992), or even wholeanimal energy metabolism in general (Chaui-Berlinck et al. 2002; Chaui-Berlinck et al. 2004). Perhaps, avian species are actively suppressing metabolism as $T_{b}$ increases within the TNZ (e.g., hyperthermia-induced hypometabolism; Lovegrove et al. 2014), explaining the apparent lack of a $\mathrm{Q}_{10}$ effect. To the best of our knowledge, however, no exact physiological mechanisms have been presented to explain this phenomenon.

Although both species increased $\mathrm{T}_{\mathrm{b}}$ with $\mathrm{T}_{\mathrm{a}}$, absolute limits of $\mathrm{T}_{\mathrm{b}}$ remained low compared to that of other avian taxa under similar conditions of heat stress. For example, at $\mathrm{T}_{\mathrm{a}} \approx 48{ }^{\circ} \mathrm{C}$, average $\mathrm{T}_{\mathrm{b}}$ in both nightjars was $39.9-41.0{ }^{\circ} \mathrm{C}$ (Table 1 ), compared to $43.0-$ 44.7 ${ }^{\circ} \mathrm{C}$ in three southern African ploceid passerines (Whitfield et al. 2015). In Spinifex Pigeons (Geophaps plumifera), $\mathrm{T}_{\mathrm{b}}$ increased to $43.4{ }^{\circ} \mathrm{C}$ at $\mathrm{T}_{\mathrm{a}} \approx 47-51{ }^{\circ} \mathrm{C}$ (Withers and Williams 1990), whereas over the same $T_{a}$ range the mean $T_{b}$ of Ezemvelo Freckled Nightjars was only $40.8^{\circ} \mathrm{C}$. Relatively small increases in $\mathrm{T}_{\mathrm{b}}$ are apparently common among caprimulgids when exposed to extreme $T_{a}$, highlighting their capacity to defend large $T_{a}-T_{b}$ gradients (Dawson and Fisher 1969; Lasiewski and Seymour 1972). The ability of 
caprimulgids to maintain these large thermal gradients is likely primarily attributable to the energetically efficient mechanism of gular flutter (Bartholomew et al. 1962). Presumably, this allows nightjars to nest on the bare ground where $\mathrm{T}_{\mathrm{e}}$ is high, but predation risk to incubating adults is reduced (Amat and Masero 2004).

\section{Resting metabolic rate}

A distinct TNZ was not evident for either species. Lower critical limits of thermoneutrality occurred at $\mathrm{T}_{\mathrm{a}} \approx 35-37{ }^{\circ} \mathrm{C}$. There was some indication for upper critical limits of thermoneutrality $\left(\mathrm{T}_{\mathrm{uc}}\right)$ at $\mathrm{T}_{\mathrm{a}} \approx 50{ }^{\circ} \mathrm{C}$, although the inflection points were not significant. Similar $\mathrm{T}_{\mathrm{lc}}$ values have been reported for Poorwills $\left(\mathrm{T}_{\mathrm{lc}} \approx 35^{\circ} \mathrm{C}\right.$; Bartholomew et al. 1962), Common Nighthawks $\left(\mathrm{T}_{\mathrm{lc}} \approx 35^{\circ} \mathrm{C}\right.$; Lasiewski and Dawson 1964) and Spotted Nightjars $\left(\mathrm{T}_{\mathrm{lc}}\right.$ $\approx 32{ }^{\circ} \mathrm{C}$; Dawson and Fisher 1969). Dawson and Fisher (1969) attributed a high $\mathrm{T}_{\mathrm{lc}}$ in Spotted Nightjars to a low basal metabolic rate, a phenotype common among caprimulgids (Lane et al. 2004). Several species of columbid birds (Marder and Arieli 1988; Withers and Williams 1990; McKechnie et al. 2016b) and houbara bustards (Tieleman et al. 2002b) have shown similar patterns of either a very high $\mathrm{T}_{\mathrm{uc}}$ or no discernible $\mathrm{T}_{\mathrm{uc}}$, a pattern that contrasts with the large increases in RMR at $\mathrm{T}_{\mathrm{a}}>\mathrm{T}_{\mathrm{b}}$ observed in many other avian taxa (Trost 1972; Weathers 1997; Williams 1999; Tieleman et al. 2002a; Whitfield et al. 2015; McKechnie et al 2016a). Both caprimulgids and columbids implement gular fluttering as a mechanism for evaporative heat dissipation, whereas many avian taxa (particularly passerines), only use panting to unload heat (Lasiewski and Bartholomew 1966; Bartholomew et al. 1968; Dawson 1982). The movement of the thorax associated with panting produces a larger muscular cost than that of gular fluttering, resulting in elevated metabolic rates and increased endogenous heat production (Whittow 1976). Lasiewski et al. (1966), for example, observed Zebra Finches 
(Taeniopygia castonatis) at $\mathrm{T}_{\mathrm{a}} \approx 43.5^{\circ} \mathrm{C}$ incapable of dissipating all of their metabolic heat resulting in an EHL/MHP of 0.96. Consequently, gular fluttering aids in limiting endogenous heat production thus allowing for more efficient evaporative cooling.

In addition to gular fluttering, cutaneous evaporative water loss (CEWL) appears to be an efficient mechanism for dissipating heat at high $\mathrm{T}_{\mathrm{a}}$ and low humidities, allowing for large increases in evaporative water loss with small or nonexistent increases in RMR (Marder and Arieli 1988; McKechnie and Wolf 2004; McKechnie et al. 2016b). Marder and Arieli (1988), for example, observed heat-acclimated Rock Pigeons (Columba livia) defending normothermic $\mathrm{T}_{\mathrm{b}}$ at $\mathrm{T}_{\mathrm{a}} \approx 60{ }^{\circ} \mathrm{C}$ without any discernible increases in $\mathrm{RMR}$ and suggested that this species' TNZ may extend up to $\mathrm{T}_{\mathrm{a}} \approx 65^{\circ} \mathrm{C}$. Additionally, McKechnie et al. (2016b) found that four species of austral columbids exposed to $T_{a}$ above the TNZ showed only small increases in RMR, with one species, the Namaqua Dove (Oena capensis), initiating panting/gular fluttering only at $\mathrm{T}_{\mathrm{a}} \approx 55^{\circ} \mathrm{C}$. The contribution of CEWL to TEWL is variable among avian taxa (Dawson 1982) and apparently influenced by habitat (Marder et al. 2003). To the best of our knowledge, only one study has measured CEWL in a caprimulgid (Lasiewski et al. 1971). These authors found that at $\mathrm{T}_{\mathrm{a}} \approx 35^{\circ} \mathrm{C}$ CEWL represented $51 \%$ of TEWL in a single Poorwill, suggesting that the contribution of CEWL to evaporative cooling in caprimulgids is substantial and comparable to other birds (Wolf and Walsberg 1996), at least at moderate $\mathrm{T}_{\mathrm{a}}$. If CEWL remains substantial at $\mathrm{T}_{\mathrm{a}}>\mathrm{T}_{\mathrm{b}}$, this will contribute, in concert with gular fluttering, to the low RMR values observed in nightjars during periods of high evaporative water loss.

Among Freckled Nightjars at Ezemvelo, mass-specific RMR between $\mathrm{T}_{\mathrm{a}} \approx 38$ and 48 ${ }^{\circ} \mathrm{C}$ was significantly greater (by $16 \%$ ) during summer compared to winter. The seasonal metabolic acclimatisation we documented in Freckled Nightjars, whereby RMR at thermoneutrality is lower in winter than in summer, is similar to the pattern reported for some 
other southern Hemisphere birds (Smit and McKechnie 2010), although a more recent analysis found that the direction of seasonal metabolic adjustments is more variable in subtropical species (McKechnie et al. 2015). Smit and McKechnie (2010) argued that the down-regulation of metabolism during winter in some southern hemisphere birds is primarily influenced by demands for energy and/or water conservation, and not cold tolerance as the case for temperate-zone species, although the functional significance of these seasonal adjustments remains unclear (McKechnie et al. 2015). Doucette and Geiser (2008) documented a lack of seasonal variation in metabolic rate of Australian Owlet-nightjars (Aegotheles cristatus; Aegothelidae). To the best of our knowledge, however, our study is the first to quantify seasonal adjustments in the metabolic rate of a member of the Caprimulgidae.

\section{Evaporative water loss}

In both Rufous-cheeked Nightjars and Freckled Nightjars, TEWL increased sharply above $\mathrm{T}_{\mathrm{a}}$ $=37-40{ }^{\circ} \mathrm{C}$. The magnitude of fractional increases in TEWL in our two study species was similar to that observed in other caprimulgids. Lasiewski and Dawson (1964) observed a fivefold increase in TEWL between $\mathrm{T}_{\mathrm{a}} \approx 35$ and $44^{\circ} \mathrm{C}$ in Common Nighthawks, whereas Dawson and Fisher (1969) reported a 20-fold increase in TEWL of Spotted Nightjars at $\mathrm{T}_{\mathrm{a}} \approx 56.5^{\circ} \mathrm{C}$ relative to values at $\mathrm{T}_{\mathrm{a}} \approx 23-25^{\circ} \mathrm{C}$.

At $\mathrm{T}_{\mathrm{a}} \approx 25^{\circ} \mathrm{C}$, TEWL of Rufous-cheeked Nightjars was equivalent to $3.8 \mathrm{~g} \mathrm{H}_{2} \mathrm{O}$ day $^{-1}$ and in Namaqualand Freckled Nightjars $3.2 \mathrm{~g} \mathrm{H}_{2} \mathrm{O}$ day ${ }^{-1}, 258 \%$ and 208\%, respectively, of the values predicted by Williams (1996) for arid-zone species. Similarly, TEWL of Common Nighthawks at $\mathrm{T}_{\mathrm{a}} \approx 25^{\circ} \mathrm{C}$ exceeded allometric predictions by $25 \%$ (Lasiewski and Dawson 1964). These comparatively high rates of TEWL may be due to the fact that $25^{\circ} \mathrm{C}$ is below 
the $\mathrm{T}_{\mathrm{lc}}$ in these species, and RMR is hence greater than thermoneutral values (Lasiewski and Dawson 1964). At $\mathrm{T}_{\mathrm{a}} \geq 40^{\circ} \mathrm{C}$, the rates of increase in TEWL (i.e., the slopes of mass-specific TEWL vs Ta) were 92, 78, 106 and 84\% of those predicted allometrically by McKechnie and Wolf (2010) in Rufous-cheeked, Namaqualand Freckled Nightjars, summer Ezemvelo and winter Ezemvelo Freckled Nightjars, respectively. Lasiewski and Dawson (1964) observed a rate of increase in TEWL of $1.4 \mathrm{mg} \mathrm{H}_{2} \mathrm{O} \mathrm{g}^{-1} \mathrm{hr}^{-1}{ }^{\circ} \mathrm{C}^{-1}$ between $\mathrm{T}_{\mathrm{a}} \approx 35$ and $44{ }^{\circ} \mathrm{C}$ in Common Nighthawks $\left(\mathrm{M}_{\mathrm{b}} \sim 72.5 \mathrm{~g}\right), 82 \%$ of that predicted allometrically by McKechnie and Wolf (2010). With the exception of Ezevmelo Freckled Nightjars in summer, a general pattern of low fractional increases in TEWL (i.e, shallower slopes of TEWL vs $\mathrm{T}_{\mathrm{a}}$ ) seems to emerge among the caprimulgids investigated to date, suggesting that at high $\mathrm{T}_{\mathrm{a}}$ nightjars may have lower TEWL rates than expected based on body size, consistent with the notion of highly efficient evaporative cooling in this taxon.

Both whole-animal and mass-specific summer TEWL at $\mathrm{T}_{\mathrm{a}} \geq 40^{\circ} \mathrm{C}$ were lower in Namaqualand Freckled Nightjars compared to Ezemvelo conspecifics, supporting our prediction that birds from a more arid site have lower TEWL once $\mathrm{M}_{\mathrm{b}}$ is taken into account. Moreover, the mass-specific rate of increase in TEWL was shallower in Namaqualand compared to Ezemvelo nightjars, despite the former birds being smaller than the latter, and hence contrasting with expectations from allometric scaling (McKechnie and Wolf 2010). Several studies have indicated that birds inhabiting hot, arid environments have evolved reduced TEWL rates compared to mesic counterparts (Dawson 1982; Williams 1996; Williams and Tieleman 2005). Tieleman et al. (2002a) investigated four species of lark, two mesic and two arid, and found that TEWL was $27 \%$ lower in arid compared to mesic species. Furthermore, fractional increases in TEWL at $\mathrm{T}_{\mathrm{a}} \approx 40{ }^{\circ} \mathrm{C}$ relative to $\mathrm{T}_{\mathrm{a}} \approx 25^{\circ} \mathrm{C}$ were smaller in the arid-zone species (Tieleman et al. 2002a). Our comparison of TEWL in two 
populations of Freckled Nightjars is hence consistent with the notion of rates of TEWL in arid-zone birds generally being lower than those of their mesic counterparts.

Although $\mathrm{M}_{\mathrm{b}}$ was significantly lower during summer, Ezemvelo nightjars had greater TEWL at any given $\mathrm{T}_{\mathrm{a}}$ during summer compared to winter, contrary to our prediction of a lower TEWL in summer-acclimatised individuals. Weathers and Caccamise (1978) investigated seasonal changes in the thermal physiology of Monk Parakeets (Myiopsitta monachus) and found that TEWL at $\mathrm{T}_{\mathrm{a}} \approx 20-30{ }^{\circ} \mathrm{C}$ was lower in winter, a result the authors related to reduced water availability in winter. Several workers have found that birds can significantly augment CEWL through changes in water vapour diffusion resistance via alterations in the composition of lipids in the stratum corneum (Haugen et al. 2003; MuñozGarcia et al. 2008; Williams et al. 2012). Arad et al. (1987), for example, observed an overall reduction in TEWL in dehydrated pigeons at $\mathrm{T}_{\mathrm{a}} \approx 45^{\circ} \mathrm{C}$ due to reductions in CEWL. Therefore, if CEWL represents a large percentage of TEWL in nightjars, as suggested by Lasiewski et al. (1971), phenotypic flexibility in resistance to water vapour diffusion during the dry season would likely have adaptive value.

\section{Ratio of evaporative heat loss to metabolic heat production}

Caprimulgids have long been recognized as having a pronounced capacity for evaporative cooling (Bartholomew et al. 1962; Lasiewski and Dawson 1964; Dawson and Fisher 1969; Dawson 1982) and our data for two southern African species are consistent with this notion. The efficiency of evaporative cooling in nightjars becomes apparent when compared to that of other species for which data exist. For example, at $\mathrm{T}_{\mathrm{a}} \approx 48{ }^{\circ} \mathrm{C}$, Whitfield et al. (2015) recorded average EHL/MHP ratios of 1.41, 1.46 and 1.61 in Scaly-feathered Weavers (Sporopipes squamifrons), White-browed sparrow-weavers (Plocepasser mahali) and 
Sociable Weavers (Philetairus socius), respectively. In comparison, the lowest average EHL/MHP value we recorded at $\mathrm{T}_{\mathrm{a}} \approx 48{ }^{\circ} \mathrm{C}$ was 2.47 (Table 1). Bartholomew et al. (1962) found Poorwills had an EHL/MHP ratio that was 1.8 times greater than Dawson's (1958) measurements for cardinals at $\mathrm{T}_{\mathrm{a}} \approx 40{ }^{\circ} \mathrm{C}$. The low resting metabolic rates of nightjars (Lane et al. 2004), coupled with the energetically efficient mechanism of gular fluttering, appears to allow this group of birds to rapidly dissipate heat evaporatively with only small or no increases in metabolism. In male Rufous-cheeked Nightjars, for instance, between $\mathrm{T}_{\mathrm{a}} \approx 38$ and $56{ }^{\circ} \mathrm{C}$ RMR increased by just $15 \%$ whereas TEWL increased by $845 \%$, allowing these birds to maintain a mean $\mathrm{T}_{\mathrm{b}}$ equivalent to $14.4^{\circ} \mathrm{C}$ below $\mathrm{T}_{\mathrm{a}}$. Lasiewski (1969) documented Poorwills increasing their oxygen consumption by $13 \%$ and TEWL by $750 \%$ at $\mathrm{T}_{\mathrm{a}} \approx 47{ }^{\circ} \mathrm{C}$ relative to $\mathrm{T}_{\mathrm{a}} \approx 35^{\circ} \mathrm{C}$. At $\mathrm{T}_{\mathrm{a}} \approx 56{ }^{\circ} \mathrm{C}$, Rufous-cheeked Nightjars were dissipating approximately $515 \%$ of their metabolic heat production. This value exceeds those previously reported for species that have also exhibited efficient cooling capacities (Dawson and Fisher 1969, Marder and Arieli 1988). Smith et al. (2015), for example, measured an EHL/MHP of 3.08 at $\mathrm{T}_{\mathrm{a}}=56{ }^{\circ} \mathrm{C}$ and an EHL/MHP of 3.69 at $\mathrm{T}_{\mathrm{a}}=58{ }^{\circ} \mathrm{C}$ in Mourning doves (Zenaida macroura) and White-winged doves (Zenaida asiatica), respectively. McKechnie et al. (2016b) measured an EHL/MHP ratio of 4.70 at $\mathrm{T}_{\mathrm{a}}=60{ }^{\circ} \mathrm{C}$ in Namaqua doves (Oena capensis). Therefore, to the best of our knowledge the EHL/MHP of 5.15 measured here for Rufous-cheeked Nightjars is the highest avian value yet reported.

The maximum EHL/MHP ratios estimated here were calculated on an assumed RER $=0.71$, corresponding to lipid metabolism. However, if RMR is recalculated assuming an $\mathrm{RER}=1.0$ (i.e., a thermal equivalence of $21.4 \mathrm{~J} \mathrm{~mL}^{-1} \mathrm{CO}_{2}$; Withers 1992), corresponding to carbohydrate metabolism, estimated RMR is $23 \%$ lower. Consequently, maximum EHL/MHP ratios increase by $30 \%$, with maximum evaporative cooling capacities of $7.8,6.4$, 5.6 and 4.4 in Rufous-cheeked Nightjars, Namaqualand Freckled Nightjars, summer 
Ezemvelo Freckled Nightjars and winter Ezemvelo Freckled Nightjars, respectively. This uncertainty highlights an unfortunate and largely unavoidable limitation of our approach to measuring heat tolerance at high $\mathrm{T}_{\mathrm{a}}$. The high flow rates required to keep chamber humidity low prevent accurate recordings of oxygen consumption and consequently RER. However, given that nightjars feed on the wing and must be hand-fed in captivity, we feel confident that our birds were post-absorptive during measurements and likely metabolising lipids.

At $40 \leq \mathrm{T}_{\mathrm{a}} \leq 52{ }^{\circ} \mathrm{C}$, summer Ezemvelo Freckled Nightjars were more efficient at dissipating metabolic heat compared to Namaqualand conspecifics, contrary to our prediction that evaporative cooling should be more efficient in Namaqualand birds. This result is likely due to TEWL being lower in Namaqualand compared to summer Ezemvelo Freckled Nightjars. Conversely, Freckled Nightjars at Ezemvelo had a greater EHL/MHP ratio during summer compared to winter. Since $\mathrm{RMR}$ between $\mathrm{T}_{\mathrm{a}} \approx 40-52{ }^{\circ} \mathrm{C}$ remained relatively stable across seasons, the variation in the efficiency of evaporative cooling likely reflects differences in TEWL rates rather than metabolic variation.

\section{Conclusions}

Caprimulgids' capacity for efficient evaporative cooling appears to arise from rates of evaporative water loss that are quantitatively similar to those of other birds, combined with metabolic rates that remain at minimal resting levels even when $T_{e}$ is far above $T_{b}$. Low resting metabolic heat production, together with the lack of a discernible $\mathrm{T}_{\mathrm{uc}}$, limits nightjars' endogenous heat production, minimizing their total heat load and allowing them to rapidly dissipate heat gained from the environment. Additionally, fractional rates of increase in TEWL for the two nightjars studied here were generally lower than expected for their size. Nevertheless, at high $\mathrm{T}_{\mathrm{a}}$ nightjars are still forced to evaporate substantial amounts of water 
for extended periods, raising questions as to the hydration status of these birds at sunset and how this may affect drinking patterns and prey selection.

Nightjars inhabit some of the hottest environments on the planet. For instance, several species reside in extremely hot deserts and semi-desert habitats (e.g., Common Poorwill; Egyptian Nightjar [Caprimulgus aegyptius]; Nubian Nightjar [Caprimulgus nubicus]; Sykes's Nightjar [Caprimulgus mahrattensis]; Cleere and Nurney 1998). A nocturnal lifestyle coupled with roosting and nesting in sites exposed to full solar radiation exposes nightjars to some of the highest $\mathrm{T}_{\mathrm{e}}$ experienced by any endotherms. Moreover, their nocturnal habits mean that they must often endure very high $\mathrm{T}_{\mathrm{e}}$ for extended periods between sunrise and sunset, especially in summer with lengthy daylight periods. Yet nightjars appear reluctant to use pronounced hyperthermia, especially when compared to other species exposed to high $\mathrm{T}_{\mathrm{a}}$ (Lasiewski and Seymour 1972; Whitfield et al. 2015; Noakes et al. 2016). Incubating in such conditions places additional thermoregulatory pressures on these birds because it forces incubating adults to maintain a $\mathrm{T}_{\mathrm{b}}$ within a narrow range well below $\mathrm{T}_{\mathrm{a}}$. Such thermally challenging conditions have undoubtedly exerted strong selective pressures on nightjars to evolve physiological traits that provide the basis for pronounced heat tolerance.

Ethical approval: All procedures performed in studies involving animals were in accordance with the ethical standards of the institution or practice at which the studies were conducted.

\section{Acknowledgments}

We thank Duncan MacFadyen and E. Oppenheimer \& Son for allowing us to conduct research on their properties, Pieter and Verencia Benade for their hospitality and access to their farm. Cathy Bester, Ryno Kemp and Pieter Erasmus provided valuable assistance in the 
field. Lastly, we thank Bruce Woodroffe and Awesome Tools (Cape Town, South Africa) for discounted lighting equipment. This paper was improved through the helpful comments of two anonymous reviewers. This study was approved by the University of Pretoria Animal Ethics Committee (project EC068-13) and complies with current South African laws. Funding was provided by the DST-NRF Centre of Excellence at the Percy FitzPatrick Institute and University of Pretoria. This material is based on work supported by the National Science Foundation under IOS-1122228 to B.O.W. Any opinions, findings and conclusions or recommendations expressed in this material are those of the author(s) and do not necessarily reflect the views of the National Science Foundation.

\section{References}

Amat JA, Masero JA (2004) Predation risk on incubating adults constrains the choice of thermally favourable nest sites in a plover. Anim Behav 67:293-300

Arad Z, Gavrieli-Levin I, Eylath U, Marder J (1987) Effect of dehydration on cutaneous water evaporation in heat-exposed pigeons (Columba livia). Physiol Zool 60:623-630

Bartholomew GA, Cade TJ (1963) The water economy of land birds. Auk 80:504-539

Bartholomew GA, Dawson WR (1979) Thermoregulatory behavior during incubation in heermann's gulls. Physiol Zool 52:422-437

Bartholomew GA, Hudson JW, Howell TR (1962) Body temperature, oxygen consumption, evaporative water loss and heart rate in the poor-will. Condor 64:117-125

Bartholomew GA, Lasiewski RC, Crawford EC Jr (1968) Patterns of panting and gular flutter in cormorants, pelicans, owls, and doves. Condor 70:31-34 
Bartoń K (2015) MuMIn: multi-model inference. R package version 1.15.1. http://CRAN.Rproject.org/package=MuMIn

Bates D (2006) [R] lmer, p-values and all that. https://stat.ethz.ch/pipermail/r-help/2006May/094765. Accessed 10 July 2015

Bates D, Maechler M, Bolker B, Walker S (2015) lme4: linear mixed-effects models using eigen and S4. R package version 1.1-9. https://CRAN.R-project.org/package=lme4

Boyles JG, Smit B, McKechnie AE (2012) Variation in body temperature is related to ambient temperature but not experimental manipulation of insulation in two small endotherms with different thermoregulatory patterns. J Zool 287:224-232

Brigham RM, McKechnie AE, Doucette LI, Geiser F (2012) Heterothermy in caprimulgid birds: a review of inter- and intraspecific variation in free-ranging populations. In: Ruf T, Bieber C, Arnold W, Millesi E (eds) Living in a seasonal world: thermoregulatory and metabolic adaptation. Springer, Berlin Heidelberg, pp 175-187

Calder WA Jr, Schmidt-Nielsen K (1966) Evaporative cooling and respiratory alkalosis in the pigeon. P Natl Acad Sci USA 55:750-756

Chaui-Berlinck JG, Monteiro LHA, Navas CA, Bicudo JEPW (2002) Temperature effects on energy metabolism: a dynamic system analysis. P Roy Soc Lond B Bio 269:15-19

Chaui-Berlinck JG, Navas CA, Monteiro LHA, Bicudo JEPW (2004) Temperature effects on a whole metabolic reaction cannot be inferred from its components. P Roy Soc Lond B Bio 271:1415-1419 
Cleere N, Nurney D (1998) Nightjars: a guide to the nightjars, nighthawks, and their relatives. Yale University Press, New Haven

Cowles RB, Dawson WR (1951) A cooling mechanism of the Texas nighthawk. Condor $53: 19-22$

Crawley MJ (2007) The R book. John Wiley \& Sons Ltd, West Sussex

Cunningham SJ, Martin RO, Hojem CL, Hockey PAR (2013) Temperatures in excess of critical thresholds threaten nestling growth and survival in a rapidly-warming arid savanna: a study of common fiscals. PloS ONE 8(9): e74613

Dawson WR (1958) Relation of oxygen consumption and evaporative water loss to temperature in the cardinal. Physiol Zool 31:37-48

Dawson WR (1982) Evaporative losses of water by birds. Comp Biochem Phys A 71:495509

Dawson WR, Fisher CD (1969) Responses to temperature by the spotted nightjar (Eurostopodus guttatus). Condor 71:49-53

Dexter RW (1956) Further banding and nesting studies of the eastern nighthawk. BirdBanding 27:9-16

Doucette LI, Geiser F (2008) Seasonal variation in thermal energetics of the Australian owlet-nightjar (Aegotheles cristatus). Comp Biochem Phys A 151:615-620

du Plessis KL, Martin RO, Hockey PAR, Cunningham SJ, Ridley AR (2012) The costs of keeping cool in a warming world: implications of high temperatures for foraging, 
thermoregulation and body condition of an arid-zone bird. Global Change Biol $18: 3063-3070$

du Prel JB, Hommel G, Röhrig B, Blettner M (2009) Confidence interval or p-value? Dtsch Arztebl Int 106:335-339

Faraway JJ (2006) Extending the linear model with R: generalized linear, mixed effects and nonparametric regression models. Chapman \& Hall/CRC, Boca Raton

Ganey JL (2004) Thermal regimes of Mexican Spotted Owl nest stands. Southwest Nat 49:478-486

Grant GS (1982) Avian incubation: egg temperature, nest humidity, and behavioral thermoregulation in a hot environment. Ornithological Monographs 30:1-75

Haugen MJ, Tieleman BI, Williams JB (2003) Phenotypic flexibility in cutaneous water loss and lipids of the stratum corneum. J Exp Biol 206:3581-3588

Heldmaier G, Ruf T (1992) Body temperature and metabolic rate during natural hypothermia in endotherms. J Comp Physiol B 162:696-706

Ingels J, Ribot JH, de Jong BHJ (1984) Vulnerability of eggs and young of the blackish nightjar (Caprimulgus nigrescens) in Suriname. Auk 101:388-391

Koller M (2015) robustlmm: robust linear mixed effects models. R package version 1.7-6. http://CRAN.R-project.org/package=robustlmm

Lane JE, Swanson DL, Brigham RM, McKechnie AE (2004) Physiological responses to temperature by whip-poor-wills: more evidence for the evolution of low metabolic rates in caprimulgiformes. Condor 106:921-925 
Lasiewski RC (1969) Physiological responses to heat stress in the poorwill. Am J Physiol 217:1504-1509

Lasiewski RC, Acosta AL, Bernstein MH (1966) Evaporative water loss in birds-I. Characteristics of the open flow method of determination, and their relation to estimates of thermoregulatory ability. Comp Biochem Physiol 19:445-457

Lasiewski RC, Bartholomew GA (1966) Evaporative cooling in the Poor-will and the Tawny Frogmouth. Condor 68:253-262

Lasiewski RC, Bernstein MH, Ohmart RD (1971) Cutaneous water loss in the roadrunner and poor-will. Condor 73:470-472

Lasiewski RC, Dawson WR (1964) Physiological responses to temperature in the common nighthawk. Condor 66:477-490

Lasiewski RC, Seymour RS (1972) Thermoregulatory responses to heat stress in four species of birds weighing approximately 40 grams. Physiol Zool 45:106-118

Lighton JRB (2008) Measuring metabolic rates: a manual for scientists. Oxford University Press, Oxford

Ligon JD (1968) The biology of the Elf Owl, (Micrathene whitneyi). Miscellaneous Publications Museum of Zoology, University of Michigan No. 136

Ligon JD (1969) Some aspects of temperature relations in small owls. Auk 86:458-472

Lovegrove BG, Canale C, Levesque D, Fluch G, Řeháková-Petrů M, Ruf T (2014) Are tropical small mammals physiologically vulnerable to arrhenius effects and climate change? Physiol Biochem Zool 87:000-000. doi: 10.1086/673313 
Marder J, Arieli Y (1988) Heat balance of acclimated pigeons (Columba livia) exposed to temperatures up to $60{ }^{\circ} \mathrm{C} \mathrm{T}_{\mathrm{a}}$. Comp Biochem Physiol A 91:165-170

Marder J, Withers PC, Philpot RG (2003) Patterns of cutaneous water evaporation by Australian pigeons. Israel J Zool 49:111-129

McKechnie AE, Noakes MJ, Smit B (2015) Global patterns of seasonal acclimatization in avian resting metabolic rates. J Ornithol. doi: 10.1007/s10336-015-1186-5

McKechnie AE, Smit B, Whitfield MC, Noakes MJ, Talbot WA, Garcia M, Gerson AR, Wolf BO (2016a) Avian thermoregulation in the heat: evaporative cooling capacity in an archetypal desert specialist, Burchell's sandgrouse (Pterocles burchelli). J Exp Biol 219:2137-2144

McKechnie AE, Whitfield MC, Smit B, Gerson AR, Smith EK, Talbot WA, McWhorter TJ, Wolf BO (2016b) Avian thermoregulation in the heat: efficient evaporative cooling allows for extreme heat tolerance in four southern Hemisphere columbids. J Exp Biol 219:2145-2155

McKechnie AE, Wolf BO (2004) Partitioning of evaporative water loss in white-winged doves: plasticity in response to short-term thermal acclimation. J Exp Biol 207:203210

McKechnie AE, Wolf BO (2010) Climate change increases the likelihood of catastrophic avian mortality events during extreme heat waves. Biol Lett 6:253-256

McNab BK (2006) The relationship among flow rate, chamber volume and calculated rate of metabolism in vertebrate respirometry. Comp Biochem Phys A 145:287-294. 
Muñoz-Garcia A, Cox RM, Williams JB (2008) Phenotypic flexibility in cutaneous water loss and lipids of the stratum corneum in house sparrows (Passer domesticus) following acclimation to high and low humidity. Physiol Biochem Zool 81:87-96

Noakes MJ, Wolf BO, McKechnie AE (2016) Seasonal and geographical variation in heat tolerance and evaporative cooling capacity in a passerine bird. J Exp Biol doi: 10.1242/jeb.132001

Pinheiro J, Bates D, DebRoy S, Sarkar D, R Core Team (2015) nlme: linear and nonlinear mixed effects models. R package version 3.1-121. http://CRAN.Rproject.org/package $=$ nlme

Porter WP, Gates DM (1969) Thermodynamic equilibria of animals with environment. Ecol Monogr 39:227-244

Quinn GP, Keough MJ (2002) Experimental design and data analysis for biologists. Cambridge University Press, Cambridge

R Core Team (2015) R: a language and environment for statistical computing. R Foundation for Statistical Computing, Vienna.

Smit B, Boyles JG, Brigham RM, McKechnie AE (2011) Torpor in dark times: patterns of heterothermy are associated with the lunar cycle in a nocturnal bird. J Biol Rhythm $26: 241-248$

Smit B, McKechnie AE (2010) Avian seasonal metabolic variation in a subtropical desert: basal metabolic rates are lower in winter than in summer. Funct Ecol 24:330-339 
Smith EK, O’Neill J, Gerson AR, Wolf BO (2015) Avian thermoregulation in the heat: resting metabolism, evaporative cooling and heat tolerance in Sonoran Desert doves and quail. J Exp Biol 218:3636-3646

Snyder GK, Nestler JR (1990) Relationships between body temperature, thermal conductance, $\mathrm{Q}_{10}$ and energy metabolism during daily torpor and hibernation in rodents. J Comp Physiol B 159:667-675

Sonderegger D (2012) SiZer: significant zero crossings. R package version 0.1-4. http://CRAN.R-project.org/package=SiZer

Spottiswoode CN, Jackson HD (2005a) Rufous-cheeked nightjar. In: Hockey PAR, Dean WRJ, Ryan PG (eds) Roberts birds of southern Africa, 7th edn. The Trustees of the John Voelcker Bird Book Fund, Cape Town, pp 271-272

Spottiswoode CN, Jackson HD (2005b) Freckled nightjar. In: Hockey PAR, Dean WRJ, Ryan PG (eds) Roberts birds of southern Africa, 7th edn. The Trustees of the John Voelcker Bird Book Fund, Cape Town, pp 266-268

Steyn P (1971) Notes on the breeding biology of the freckled nightjar. Ostrich 42:179-188

Swanson DL, Drymalski MW, Brown JR (1996) Sliding vs static cold exposure and the measurement of summit metabolism in birds. $\mathbf{J}$ Therm Biol 21:221-226

Tattersall GJ, Sinclair BJ, Withers PC, Fields PA, Seebacher F, Cooper CE, Maloney SK (2012) Coping with thermal challenges: physiological adaptations to environmental temperatures. Compr Physiol 2:2151-2202 
Tieleman BI, Williams JB (1999) The role of hyperthermia in the water economy of desert birds. Physiol Biochem Zool 72:87-100

Tieleman BI, Williams JB, Buschur ME (2002a) Physiological adjustments to arid and mesic environments in larks (Alaudidae). Physiol Biochem Zool 75:305-313

Tieleman BI, Williams JB, LaCroix F, Paillat P (2002b) Physiological responses of houbara bustards to high ambient temperatures. J Exp Biol 205:503-511

Trost CH (1972) Adaptations of horned larks (Eremophila alpestris) to hot environments. Auk 89:506-527

Walsberg GE, Voss-Roberts KA (1983) Incubation in desert-nesting doves: mechanisms for egg cooling. Physiol Zool 56:88-93

Weathers WW (1981) Physiological thermoregulation in heat-stressed birds: consequences of body size. Physiol Zool 54:345-361

Weathers WW (1997) Energetics and thermoregulation by small passerines of the humid, lowland tropics. Auk 114:341-353

Weathers WW, Caccamise DF (1978) Seasonal acclimatization to temperature in monk parakeets. Oecologia 35:173-183

Weathers WW, Schoenbaechler DC (1976) Regulation of body temperature in the budgerygah, Melopsittacus undulatus. Aust J Zool 24:39-47

Weller MW (1958) Observations on the incubation behavior of a common nighthawk. Auk $75: 48-59$ 
Whitfield MC, Smit B, McKechnie AE, Wolf BO (2015) Avian thermoregulation in the heat: scaling of heat tolerance and evaporative cooling capacity in three southern African arid-zone passerines. J Exp Biol 218:1705-1714.

Whittow GC (1976) Regulation of body temperature. In: Sturkie PD (ed) Avian physiology, 3rd edn. Springer-Verlag, New York, pp 146-173

Williams JB (1996) A phylogenetic perspective of evaporative water loss in birds. Auk $113: 457-472$

Williams JB (1999) Heat production and evaporative water loss of dune larks from the Namib desert. Condor 101:432-438

Williams JB, Muñoz-Garcia A, Champagne A (2012) Climate change and cutaneous water loss of birds. J Exp Biol 215:1053-1060

Williams JB, Tieleman BI (2005) Physiological adaptation in desert birds. BioScience $55: 416-425$

Withers PC (1977) Respiration, metabolism, and heat exchange of euthermic and torpid poorwills and hummingbirds. Physiol Zool 50:43-52

Withers PC (1992) Comparative animal physiology. Saunders College Publishing, Orlando

Withers PC, Williams JB (1990) Metabolic and respiratory physiology of an arid-adapted Australian bird, the spinifex pigeon. Condor 92:961-969

Wolf BO, Walsberg GE (1996) Respiratory and cutaneous evaporative water loss at high environmental temperatures in a small bird. J Exp Biol 199:451-457 